\title{
Safety as a management concept in the air transport sector: A systematic literature review
}

\author{
Nicole Kalemba (D), Fernando Campa-Planas (D) \\ Universitat Rovira i Virgili (Spain) \\ nicole.kalemba@urv.cat,fernando.campa@urv.cat
}

Received October, 2016

Accepted November, 2016

Versión en español

\section{Abstract}

Purpose: The main purpose of the present study is to conduct a literature review of the contribution made by safety in air transport, based on the existing international academic literature in the field of the social sciences. It primarily attempts to examine and verify the relationship between safety-related concepts (co-occurrence), the link between the different authors (co-authorship) and the corresponding citations (co-citations).

Design/methodology: To achieve the established objectives, a systematic literature review (SLR) has been conducted using the Scopus database between the years 1990 and 2016, identifying international academic papers related to the research topic of the present study.

Findings: It has been verified, on the one hand, that safety in the air transport sector is a field of growing interest, as the number of papers has increased considerably in recent years, thus demonstrating the importance that this topic has acquired over time. On the other hand, however, it must be mentioned that the total quantity of papers related to the topic is low in terms of absolute numbers.

The results of the co-occurrence analysis show that the most important aspect of safety is safety management, while the strongest link is between safety management and aircraft accidents, a fact that is foreseeable a priori. 
Originality/value: The approach used allows a better view of the academic contribution made in relation to safety; this serves as the link among the different elements of the concept studied, and it demonstrates the growing interest in this area.

Keywords: Safety, Air transport, Airlines, Quality, Profitability, Systematic literature review

Jel Codes: J28, L93

\section{Introduction}

The air transport sector is an essential provider of a wide range of services, and is a fast-growing industry faced with a large number of challenges when it comes to generating benefits, due to the numerous events and trends that influence it, both social and economic (IATA, 2014; ATAG, 2014).

Within the large variety of circumstances that have an influence on the air transport sector, a key element is offering operations with a high level of safety and efficiency to passengers on a global level (ICAO, 2015), as well as ensuring the safety and security of the people who work around the aircraft and the safety of the aircraft themselves (AERTEC, 2013).

Air transport stands out from other alternative means due to factors such as speed, cost, efficiency, comfort and flexibility (Kelemen, 2003; ATAG, 2014), in addition to its safety conditions, which are much higher than those of other types of transport, such as road, rail, etc. (Pacheco, Fernandes \& Domingos, 2014).

Improved safety standards have always been one of the main priorities in the sector, if not the top priority (Liou, Yen \& Tzeng, 2008). There is little doubt that it is a concept that plays an essential role and its improvement has become a topic of growing interest in the field of operation management (McFadden \& Hosmane, 2001). The air transport industry is also known for its efforts and the unending challenge of always wanting to be known for its high level of safety and security, therefore reducing the number of accidents and incidents (Shappell, Detwiler, Holcomb, Hackworth, Boquet \& Wiegmann, 2007; Liao, 2015). 
While the number of passengers in this sector is continuously on the rise, the number of passengers who are victims of accidents is decreasing in absolute values, and therefore, to a greater extent, in relative values (Aviation Safety Network, 2016; ICAO, 2015).

However, due to the difficulty of defining the aspects that are included within the framework of operational safety, the main objective of the study is to obtain a broad view of the contributions made in the literature about safety in air transport and its evolution over time, as well as to determine the concepts that are most closely related to it (co-occurrence).

To reach said objective, the necessary information has been examined and collected through a systematic revision of the literature, using the Scopus database.

Other more specific objectives, taking into account the present research topic at all times, are the following:

- To see the evolution of the academic publications related to safety in air transport during the period 1990-2016 (understanding 2016 as the review completed prior to February 29 of this year).

- To obtain an overview of the main journals considering the research topic.

- To identify which are the most frequently cited academic articles and their corresponding researchers.

- To determine the relationship among the different researchers (co-authorship).

- To see the co-citation among the documents included in this study.

- To show and analyze the origin of the authors of the related articles.

The main contribution of this article is therefore the description and dissemination of what has been said about safety in the air transport sector in recent decades, the authors that stand out and the relationship between the established variables and the concept of safety.

The present document has been structured as follows: first, the field of interest and research topic are introduced, that is to say, safety in air transport; secondly, the methodology used to conduct the research is described; the third section presents the results obtained, while the last part discusses the main conclusions drawn. 


\section{The conceptual framework and evolution of operational safety}

The intent of this section is to analyze the concept of operational safety, as well as to show the evolution of said concept over time.

\subsection{Dual of interpretation}

Before defining this concept, it is necessary to comment on the need for a correct interpretation of two concepts highly related in the air transport field: safety and security.

One concept is safety, which refers to concepts related to incidents and accidents involving air transport (AERTEC, 2013), while the other aspect is the security, related to, for example, "criminal acts and illicit interference" (AERTEC, 2013), which can affect the protection of both passengers and ground and air crews, among others. Security can thus affect, to a greater or lesser extent, safety.

Both safety and security have always been two key objectives and a great challenge in the air transport sector (Fox, 2014), and more so since the events of September 2001 in the United States. According to Barnett (2009), the two factors that passengers most commonly relate to safe travel is one, avoiding airplane accidents, and two, the prevention of criminal and terrorist incidents.

\subsection{Operational safety}

According to AERTEC (2013), safety works when the possibility of accidents and incidents and injuries or damage to passengers, property and staff members is reduced, thanks to the ongoing process of analysis and management of both dangers and risks.

The International Civil Aviation Organization (ICAO) defines safety in a similar manner, as a state in which the possibility of personal injury or property damage is reduced, and an attempt is made to keep it low and controlled through continuous risk analysis, among other measures.

In other words, safety refers to the act of reducing both accidents and incidents as much as possible. Per AERTEC (2013), three criteria need to be considered in order to define safety: first of all, how to evaluate and detect risks in order to keep them at an acceptable low level; secondly, how to investigate 
incidents in order to make the right preventive decisions and finally, how to define safety variables and indicators that make it possible to measure and monitor the safety level.

\subsection{Evolution of safety in recent years}

As mentioned earlier, the number of passengers has continually increased, while the number of fatal accidents has significantly decreased in recent decades, as shown in Figure 1.

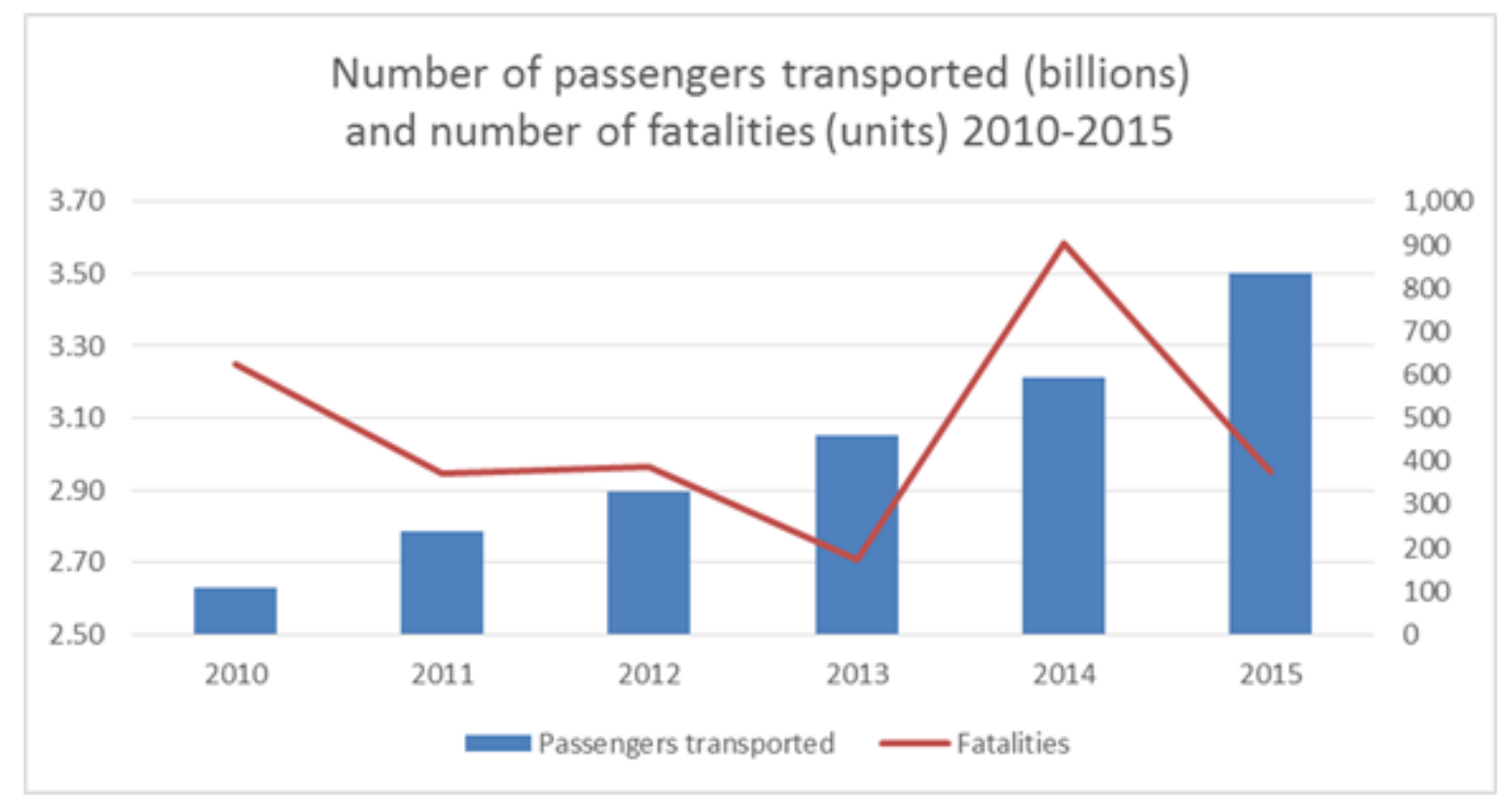

Figure 1. Number of passengers and number of fatal accidents 2010-2015 (author's own work based on data of the World Bank (2015) and ICAO (2015))

Figure 1 shows the constant growth in the number of passengers, which reached 3.5 billion in 2015, representing an increase of $8.9 \%$ over 2014 .

According to the European Aviation Safety Agency (EASA, 2015), the number of fatal accidents in 2014 was below the average total for the last 10 years (2004-2013), in spite of the fact that 2014 (see Figure 1) was a year that stands out for the number of fatalities $(\mathrm{n}=904)$. 
The year 2014 includes two unique accidents, Malaysia Airlines Flight 370 (which disappeared in March 2014; there is still no evidence as to its cause), and Flight 17 from the same company, which was attacked as it flew over Ukraine in July 2014.

\section{Methodology}

The methodology followed in the present study is as follows: first, a systematic review was conducted of the literature (hereinafter referred to as the systematic literature review or SLR), using the bibliographic database Scopus, which provides a broad overview of international academic articles, including a large database of summaries and citations (Elsevier, 2015).

The systematic literature review methodology is an essential tool for any project in academia, as it helps add to the knowledge researchers need about a specific topic (Webster \& Watson, 2002). It also has the advantage of providing rigorous, exhaustive, reliable and unbiased information (Kitchenham, 2004).

Kitchenham (2004) also mentions two fundamental aspects that make SLR necessary, namely, the identification of gaps in order to propose future lines of research and also to present background information as a framework.

In most cases, SLR has been used in the field of health (CRD, 2009) and other disciplines, such as public policy, but it has also been applied in relation to the air transport sector (Ginieis, Sánchez-Rebull \& Campa-Planas, 2012a-b).

All this shows that SLR is a very useful tool for the evaluation and analysis of the available information and its later interpretation in response to the research question to be studied (Kitchenham, 2004).

The SLR conducted for the present study covers the period between 1990 and February 2016, thus encompassing an extended period, which enables us to obtain an overview of the evolution of the concept of safety in air transport.

Secondly, for the co-authorship and co-citation analysis among the different articles, as well as to compare the variables (co-occurrence) related to safety, the program NodeXL Template for Microsoft Excel 2007 was used to facilitate the identification of the concepts and to create a network analysis that is visualized in a way that makes it easy to see the existing relationships among the different variables (NodeXL, 2013). 


\subsection{Identification of key words and article sampling}

To identify the publications related to the present study, different combinations of a total of nine key words (three primary and six secondary key words) were established, as shown below:

- Safety AND Airlines OR Air Transportation AND Profitability

- Safety AND Airlines OR Air Transportation AND Quality

- Safety AND Airlines OR Air Transportation AND Cost Maintenance

- Safety AND Airlines OR Air Transportation AND Management

- Safety AND Airlines OR Air Transportation AND Performance

- Safety AND Airlines OR Air Transportation AND Success

As can be seen in Table 1, considering the different combinations of primary and secondary key words, the total number of articles found in the Scopus database within the field of the social sciences after the first search was 1,021. This figure includes conference presentations and book chapters which were later eliminated for the final review.

\begin{tabular}{|l|r|}
\hline \multicolumn{1}{|c|}{ Combination of key words } & Number of articles found \\
\hline Safety AND Airlines AND Profitability & 17 \\
\hline Safety AND Air Transportation AND Profitability & 9 \\
\hline Safety AND Airlines AND Quality & 62 \\
\hline Safety AND Air Transportation AND Quality & 126 \\
\hline Safety AND Airlines AND Cost Maintenance & 15 \\
\hline Safety AND Air Transportation AND Cost Maintenance & 8 \\
\hline Safety AND Airlines AND Management & 193 \\
\hline Safety AND Air Transportation AND Management & 299 \\
\hline Safety AND Airlines AND Performance & 105 \\
\hline Safety AND Air Transportation AND Performance & 147 \\
\hline Safety AND Airlines AND Success & 23 \\
\hline Safety AND Air Transportation AND Success & 17 \\
\hline \multicolumn{2}{|c|}{ Total papers } \\
\hline
\end{tabular}

Table 1. Results of the search in the Scopus database

The search criterion and subsequent filtering of the articles after eliminating duplicates was based on the requirement that at least one of the key words must be used in the title, the article abstract or the keywords specified by each of the authors. 
According to this procedure, the final bibliographic database consisted of 59 international academic articles, which were used as the basis for the present study, as shown in Table 2.

\begin{tabular}{|l|r|r|}
\hline \multicolumn{1}{|c|}{ Article filter } & \multicolumn{1}{|c|}{$\begin{array}{c}\text { Articles } \\
\text { eliminated }\end{array}$} & $\begin{array}{c}\text { Total articles considered } \\
\text { for the SLR }\end{array}$ \\
\hline Total initial main search & $(405)$ & 1,021 \\
\hline Elimination of duplicates & $(557)$ & 616 \\
\hline Elimination of articles based on the search criteria & $\mathbf{5 9}$ \\
\hline
\end{tabular}

Table 2. Final sample of articles included in the literature review

\subsection{Encoding operational safety variables}

After reviewing and reading the aforementioned 59 articles about operational safety and with the collaboration of a panel of experts, 11 key variables were determined that were derived from their reading. The variables detected were the following:

1. Aircraft accidents: Related to airplane accidents, collision, etc.; events that generate the death or serious injury of people, and in which the aircraft is substantially damaged.

2. Aircraft incidents: An event different from an operational accident, it is related to the operation and use of an aircraft that can affect safety.

3. Aircraft related issues: Aspects related to the aircraft, i.e., the type of aircraft, age of the fleet, etc.

4. Customer related issues: Includes aspects such as customer satisfaction, perception, behavior, etc.

5. Human factors: This variable covers both human errors and human resource management, among other aspects.

6. Maintenance: Aircraft maintenance is related to aspects such as the repair, inspection, general inspection, failure mechanisms, etc.

7. Safety culture: Includes everything related to the culture surrounding safety, such as the commitment and dedication to safety, the definition of obligations and the responsibilities of employees, etc. 
8. Safety management: A management variable of safety that includes aspects such as safety management programs and systems, as well as risk management and analysis.

9. Safety performance: Aspects associated with financial stability, economic and financial profitability, the financial health of the airline, etc.

10. Security: Includes everything related to physical security, such as the protection of passengers, ground and flight crews, the aircraft itself, etc.

11. Technical flight crew: The technical flight crew variable includes aspects such as the communications skills of the employees, their training and the pilot's experience (i.e. total flight time), among other aspects.

All variables were necessary in order to establish and then demonstrate the relationship that exists among the different concepts included (co-occurrence) during the SLR, and thus determine which topics were dealt with most often during the analyzed period.

\section{Descriptive results}

This section shows the descriptive results obtained from the 59 articles from the Scopus database, along with the 134 authors included in the study and resulting of said articles, for the period 1990February 2016 covered by the present study.

\subsection{Evolution of the academic articles on operational safety}

Figure 2 shows the evolution over time of the final selection of international academic articles $(n=59)$ that have been selected following an exhaustive SLR.

In particular, during the period 2012-2015, the number of publications has increased significantly, representing $42.37 \%$ of the total analyzed. This total reflects the growing importance of the topic studied in recent years. 


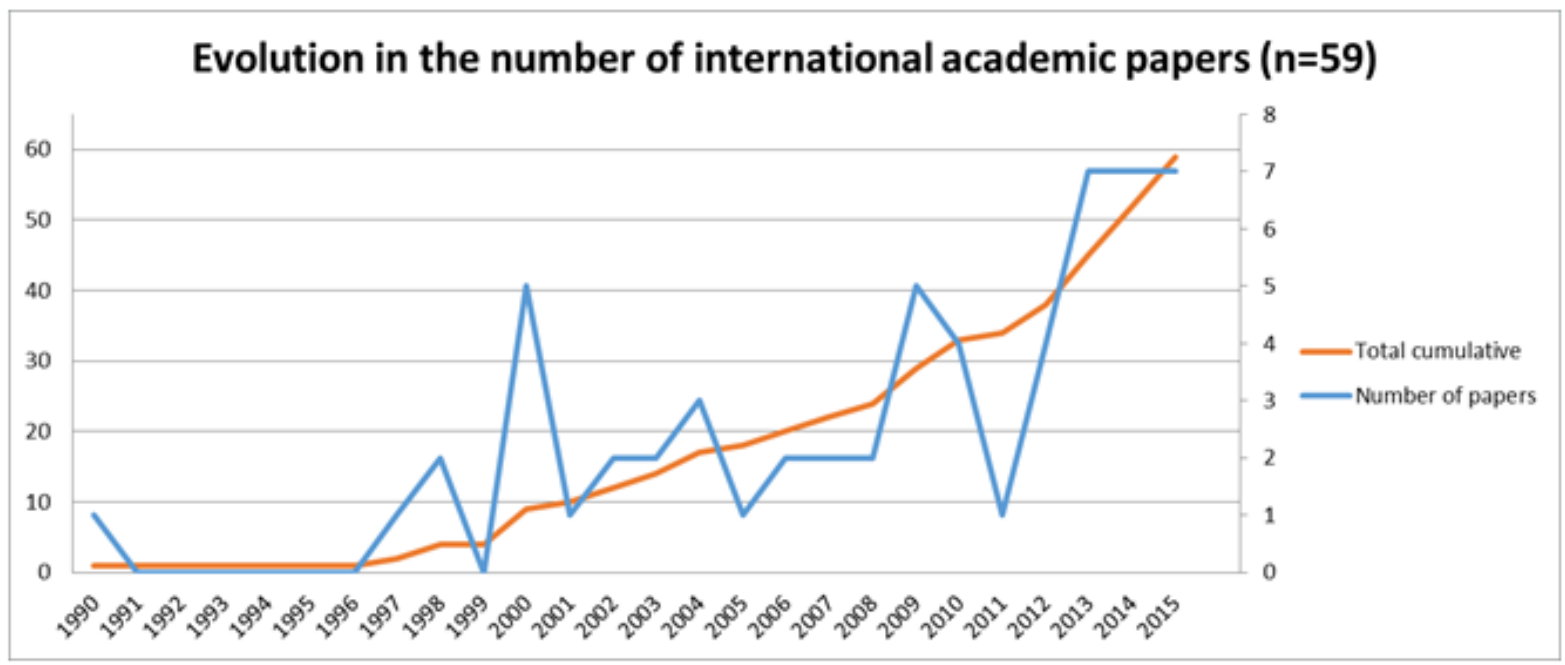

Figure 2. Evolution in the number of international academic articles during the years 1990-2015

As also can be seen, during the years 1990-1997, very few (practically no) articles were published. It is only after 2000 and especially since 2006 when the topic begins to grow as a research topic, although it must be stressed that, in general, the total number of articles in terms of absolute value is very low in relation to other studies in the field of air transport (Ginieis, Sánchez-Rebull \& Campa-Planas, 2012a-b; Kalemba \& Campa-Planas, 2016).

\subsection{Most productive and most frequently cited journals}

This section analyzes which journals are the most productive and most often cited in this study, with reference to the topic addressed in this SLR, taking into account the 59 articles obtained from the systematic literature review and their corresponding ranking.

\begin{tabular}{|r|l|r|r|r|c|}
\cline { 2 - 6 } \multicolumn{1}{c|}{ Journal name } & \multicolumn{1}{|c|}{$\begin{array}{c}\text { No. of articles } \\
\text { in the study }\end{array}$} & \multicolumn{1}{c|}{$\begin{array}{c}\text { No. of } \\
\text { citations }\end{array}$} & $\begin{array}{c}\text { Impact factor } \\
\text { at 5 years }\end{array}$ & Quartile \\
\hline $\mathbf{1}$ & Journal of Air Transport Management & 16 & 463 & 1.328 & Q1/Q2 \\
\hline $\mathbf{2}$ & Safety Science & 14 & 98 & 2.210 & Q1 \\
\hline $\mathbf{3}$ & $\begin{array}{l}\text { International Journal of Industrial } \\
\text { Ergonomics }\end{array}$ & 3 & 110 & 1.366 & Q2 \\
\hline $\mathbf{4}$ & Accident Analysis \& Prevention & 2 & 27 & 2.699 & Q1 \\
\hline $\mathbf{5}$ & Applied Ergonomics & 2 & 2.143 & Q1 \\
\hline $\mathbf{6}$ & Quality Progress & 2 & 2 & ND & Q4 \\
\hline $\mathbf{7}$ & Research in Transportation Economics & 2 & ND & Q1/Q2 \\
\hline $\mathbf{8}$ & $\begin{array}{l}\text { Transportation Research Part E: Logistics } \\
\text { and Transportation Review }\end{array}$ & 28 & 3.513 & Q1 \\
\hline
\end{tabular}

Table 3. The most productive and most frequently cited journals according to the systematic literature review 
Table 3 shows the most productive journals and those that have at least 2 or more articles included in the present study $(n=8)$, as well as their impact factor at 5 years and the quartile to which each journal corresponds, according to its category.

The first two journals, the Journal of Air Transport Management (United Kingdom) and Safety Science (Netherlands) represent more than $50 \%$ of the publications out of the total number of articles included in the study (30 of 59 articles), thus demonstrating that the articles are concentrated in a small number of journals.

The Journal of Air Transport Management $(n=16)$ is in first position, with 463 citations, and it is also the most specific journal in terms of air transport.

It should also be mentioned that at the same time it is the journal with the lowest impact factor at 5 years, as a journal in the first/second quartile in the subcategories of law, management and transport (SCImago Journal \& Country Rank, 2014).

On the other hand, the journal Safety Science is found in the first quartile in the subcategories of health and safety (SCImago Journal \& Country Rank, 2014).

\subsection{Most frequently cited articles}

Table 4 provides information on the articles most frequently cited, considering the authors, the title and the year of publication, as well as the total number of citations since publication.

\begin{tabular}{|r|l|l|r|r|}
\cline { 2 - 5 } \multicolumn{2}{|c|}{ Authors } & \multicolumn{1}{c|}{ Title } & \multicolumn{1}{c|}{ Year } & \multicolumn{1}{c|}{ Cites } \\
\hline $\mathbf{1}$ & Liou, J.J.H., Tzeng, G.H., Chang, H.C. & Airline safety measurement using a hybrid model & 2007 & 164 \\
\hline $\mathbf{2}$ & Liou, J.J.H., Yen, L., Tzeng, G.H. & Building an effective safety management system for airlines & 2008 & 83 \\
\hline $\mathbf{3}$ & Janic, M. & An assessment of risk and safety in civil aviation & 2000 & 61 \\
\hline $\mathbf{4}$ & Latorella, K.A., Prabhu, P.V. & $\begin{array}{l}\text { A review of human error in aviation maintenance and } \\
\text { inspection }\end{array}$ & 2000 & 55 \\
\hline $\mathbf{5}$ & Chang, Y.H., Yeh, C.H. & A new airline safety index & 2004 & 37 \\
\hline $\mathbf{6}$ & Netjasov, F., Janic, M. & $\begin{array}{l}\text { A review of research on risk and safety modelling in civil } \\
\text { aviation }\end{array}$ & 2008 & 34 \\
\hline $\mathbf{7}$ & $\begin{array}{l}\text { Rankin, W., Hibit, R., Allen, J., } \\
\text { Sargent, R. }\end{array}$ & $\begin{array}{l}\text { Development and evaluation of the Maintenance Error } \\
\text { Decision Aid (MEDA) process }\end{array}$ & 2000 & 33 \\
\hline $\mathbf{8}$ & Gill, G.K., Shergill, G.S. & $\begin{array}{l}\text { Perceptions of safety management and safety culture in the } \\
\text { aviation industry in New Zealand }\end{array}$ & 2004 & 33 \\
\hline $\mathbf{9}$ & Lee, W.K. & Risk assessment modeling in aviation safety management & 2006 & 30 \\
\hline $\mathbf{1 0}$ & Taylor, J.C. & $\begin{array}{l}\text { The evolution and effectiveness of Maintenance Resource } \\
\text { Management (MRM) }\end{array}$ & 2000 & 22 \\
\hline
\end{tabular}

Table 4. Most frequently cited academic articles base on the systematic literature review 
The most cited article was that by Liou, Tzeng and Chang (2007), entitled Airline safety measurement using a hybrid model, which received a total of 164 citations. It was followed by an article by the same author, Liou et al. (2008), entitled Building an effective safety management system for airlines, which was cited a total of 83 times. Both articles were published in the aforementioned Journal of Air Transport Management.

\subsection{Relationship among authors (co-authorship)}

In order to demonstrate the collaboration among the different authors established by the articles selected as part of the SLR, a co-authorship map has been created.

During the evolution of the time considered in the study, the scientific works were increasingly coauthored, and following this trend, the phenomenon of co-authorship has attracted interest in recent years (Acedo, Barroso, Casanueva \& Galán, 2006).

The 59 academic articles selected were written by a total of 134 authors, of whom 13 have contributed to two and even three articles. The two most productive authors have been Chen, C.F. (2012, 2014, 2014) and Chen, S.C. (2012, 2014, 2014), both of whom have collaborated on the three occasions with one another.

Figure 3 shows this information on co-authorship in graphic form. 


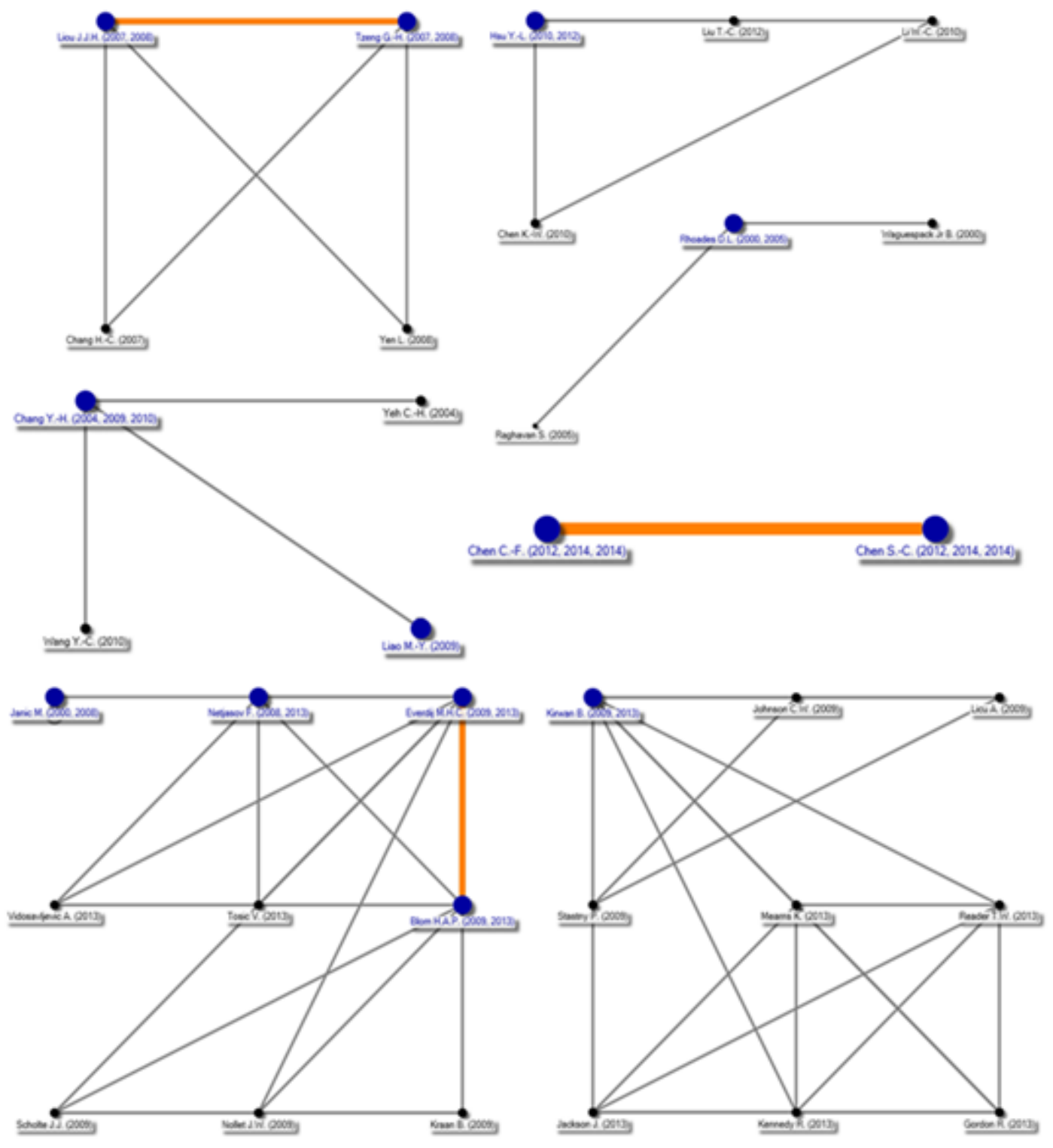

Figure 3. Co-authorship among the authors (author's own work, using NodeXL)

It should be mentioned that $32.20 \%$ of the 59 articles have been written by two authors ( $\mathrm{n}=19$ ), $30.51 \%$ by a single author and $23.73 \%$ by three authors. The remaining $13.56 \%$ were written by 4 to 6 authors. 


\subsection{Relationship among cited articles (co-citation)}

Co-citation analysis has become a necessary and predominate method for scientific works in recent years, and it has already been applied in a number of studies (Seguí-Mas, Sarrión-Viñes, Tormo-Carbó \& Oltra, 2016; Alves, Fernandes \& Raposo, 2016). It is a tool that helps analyze different groups of researchers, revealing their publications and fields of application (Alves et al., 2016), as well as observing similarities in the content by the cited authors (Gmür, 2003).

Figure 4 shows a co-citation map of the authors of the articles with the largest number of citations in relation to safety, taking into account the criterion that the number of citations was greater than or equal to $50(\mathrm{n}=4)$. For all cases, only the first author of each article was included and then all authors with less than two citations were eliminated in order to obtain a better view of the co-citations among the authors.

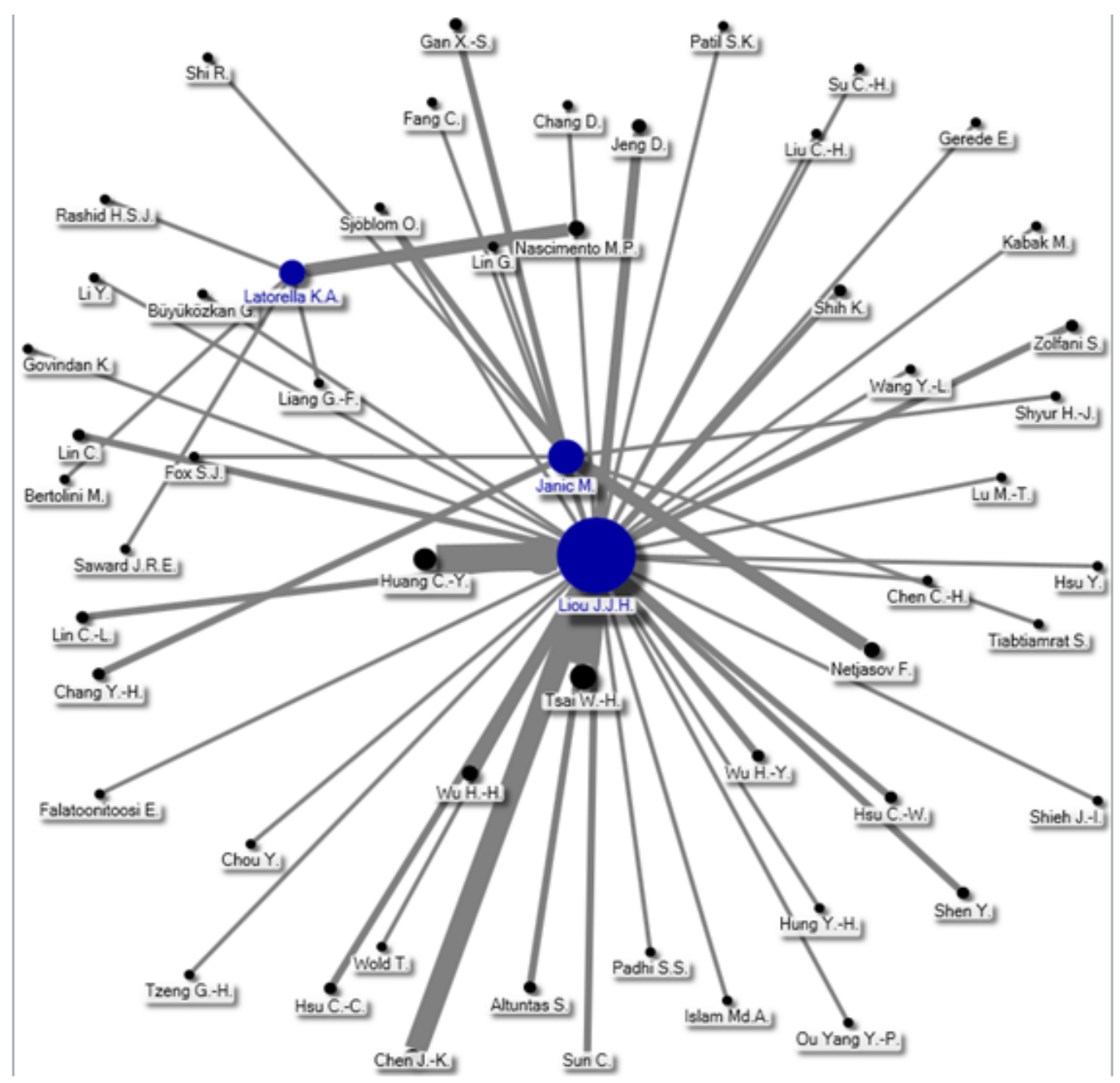

Figure 4. Co-citation among authors (author's own work, using NodeXL) 
The most frequently cited authors were Liou (2007, 2008) and Janic (2000), with 116 and 24 citations, respectively. The greatest co-occurrence of citations exists between Liou \& Huang ( $\mathrm{n}=13)$ and Liou \& Tsai $(\mathrm{n}=13)$.

\subsection{Origin of the authors}

In order to observe the spatial distribution and to study where else the present research topic has been given attention, the origin of each of the authors was analyzed. Figures 5 and 6 show the 17 countries in which the topic of operational safety in air transport has been studied.

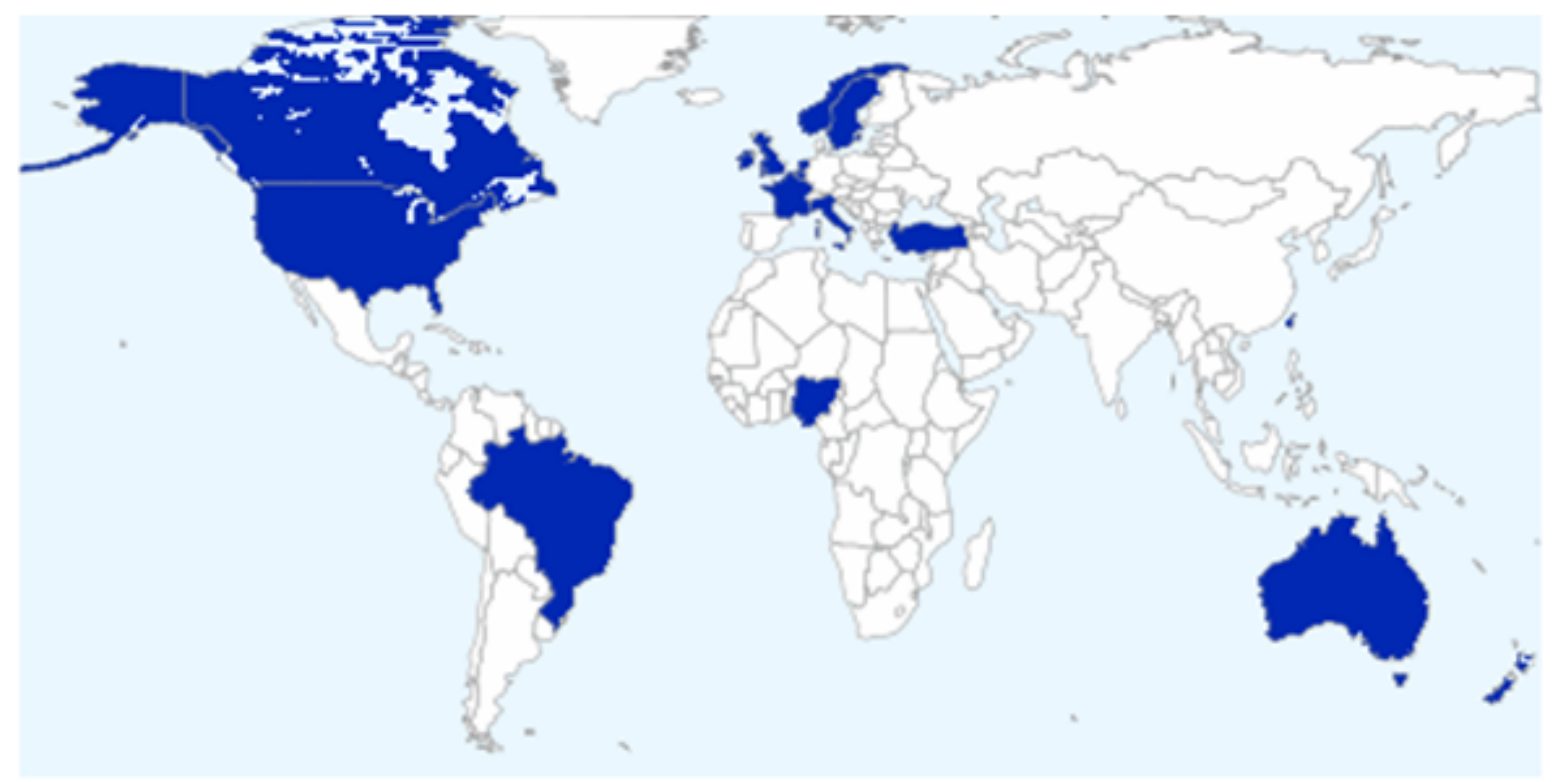

Figure 5. Origin of authors by country

Among the countries included, the United States and Taiwan predominated, representing 24.6\% (33 authors) and 23.95\% (32 authors) of the authors, respectively, out of a total of 134 authors of the articles included in the literature review.

The countries belonging to the European Union with the largest proportion of authors are the United Kingdom (10.4\%) and the Netherlands (6.0\%). 


\begin{tabular}{|l|c|c|}
\hline Origin of the authors & Number of authors & Percentatge/total \\
\hline United States & 33 & $24.6 \%$ \\
\hline Taiwan & 32 & $23.9 \%$ \\
\hline United Kingdom & 14 & $10.4 \%$ \\
\hline Australia & 13 & $9.7 \%$ \\
\hline Norway & 9 & $6.7 \%$ \\
\hline Netherlands & 8 & $6.0 \%$ \\
\hline New Zealand & 5 & $3.7 \%$ \\
\hline Italy & 4 & $3.0 \%$ \\
\hline Serbia & 4 & $3.0 \%$ \\
\hline Brazil & 3 & $2.2 \%$ \\
\hline Belgium & 2 & $1.5 \%$ \\
\hline Canada & 2 & $1.5 \%$ \\
\hline France & 1 & $0.7 \%$ \\
\hline Ireland & 1 & $0.7 \%$ \\
\hline Nigeria & 1 & $0.7 \%$ \\
\hline Sweden & 1 & $0.7 \%$ \\
\hline Turkey & 1 & $0.7 \%$ \\
\hline & & \\
\hline
\end{tabular}

Figure 6. Origin of authors by country

\subsection{Analysis of the network of variables related to safety}

In order to demonstrate the relationship among the different concepts that are linked to safety, as discussed in the basic literature, a co-occurrence analysis was conducted on the keys aspects.

A map of the co-occurrences was created (see Figure 7) using the NodeXL tool (NodeXL, 2013), considering the eleven variables mentioned earlier, which were determined based on the 59 articles included in the SLR.

This figure is shown according to the design by Fruchterman and Reingold (1991), based on the one hand on edges, which show the importance and the frequency of the co-occurrence between two variables, and on the other hand, the volume of each of the nodes, which represent the relevance of each of the variables. 


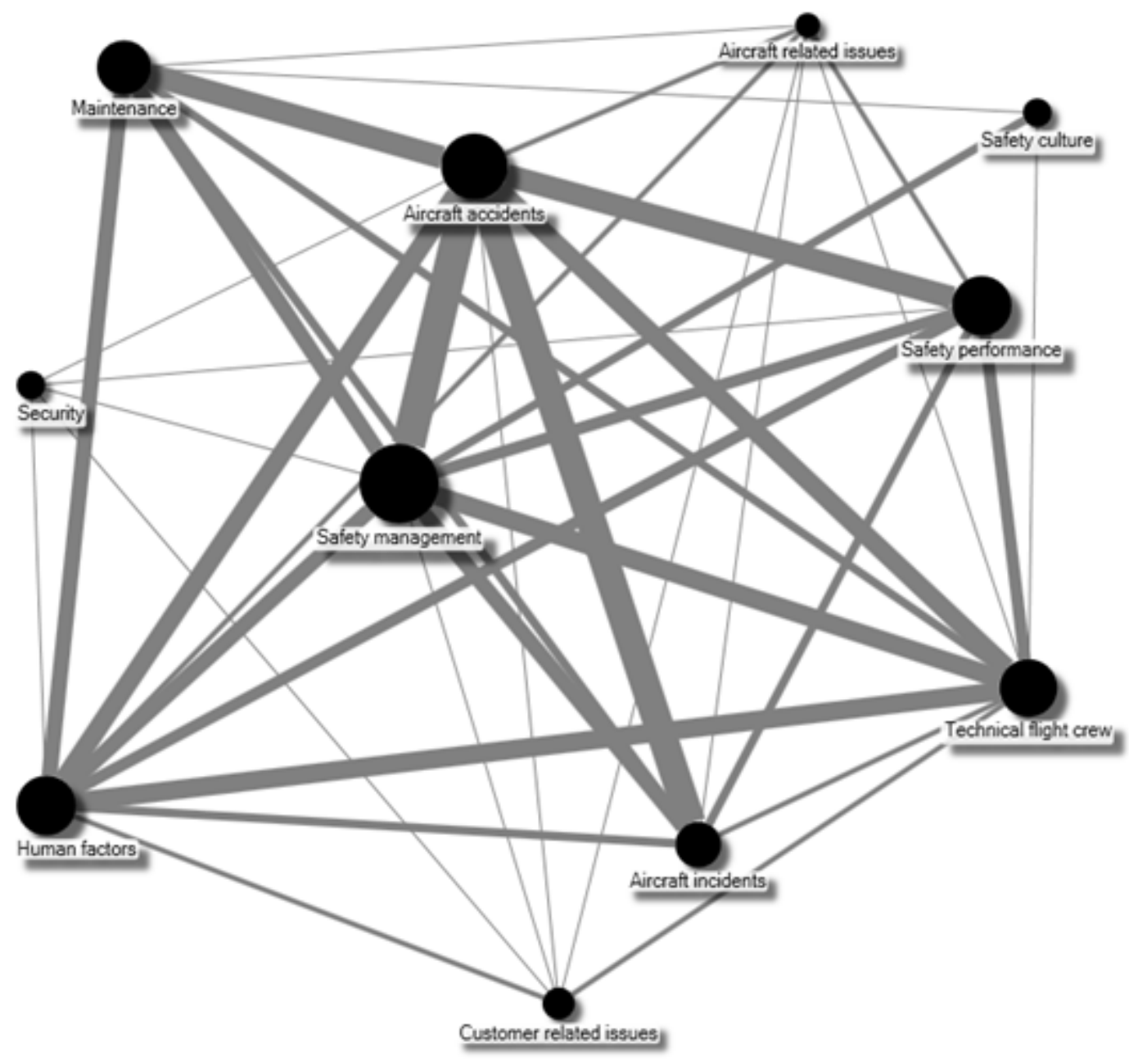

Figure 7. The relationship among the established variables in reference to safety (author's own work, using NodeXL)

As can be seen in Figure 7, the node with the greatest weight, i.e., the concept most used in relation to safety in the international academic literature is Safety management $(n=30)$, followed by Aircraft accidents $(n=22)$, while the strongest link is shown between the variables of Safety management and Aircraft accidents, and between Safety management and Aircraft incidents. Figure 7 also shows that the other variables most commonly used in relation to the concept of safety are Human factors, Safety performance and the Technical flight crew. 


\section{Conclusions}

In spite of the fact that safety is a key element in the air transport sector, it must be mentioned that no specific literature review article in the sector has considered the contribution made by the concept studied in this article.

Therefore, the study has attempted to bridge this gap and conduct a systematic literature review (SLR), using the Scopus database. This review enabled us to identify international academic articles corresponding to the proposed research topic.

The most frequently cited journals and articles were examined, in addition to determining the degree of co-occurrence among the variables established by the authors in relation to safety, with the help of a panel of experts; an overview of the co-authorship and co-citations among the different authors was also provided. Starting with a total of 1,021 articles, once the selected articles were refined, a sample of 59 articles published between 1990 and February 2016 were analyzed.

The first conclusion that we can comment on is that the research topic is one of growing interest, even though the total number of articles in terms of absolute value continues to be very low.

Most of the articles obtained after the preliminary search have been primarily related to the field of psychology and engineering, and only a few articles are based on management topics and relevant concepts in relation to safety.

The most productive journal in terms of both the total number of articles included $(n=16)$ and the total number of citations ( $\mathrm{n}=463)$ was the Journal of Air Transport Management. In second place was the journal Safety Science, in terms of the total number of articles included in the study $(n=14)$, while the journal with the second largest number of citations was the International Journal of Industrial Ergonomics, with 110 citations.

The two most frequently cited articles were both published by Liou et al., in 2007 and 2008, and were entitled Airline safety measurement using a bybrid model and Building an effective safety management system for airlines, respectively.

Through a network analysis, it was possible to obtain a co-occurrence map of the different variables established as the result of the SLR and their subsequent definition. Thanks to this, it was possible to acquire an overview of the structure of the basic literature dedicated to this research topic. 
The most relevant concepts with the greatest relative weight with regard to operational safety were Safety management and Aircraft accidents, while the edges with the highest degree of interaction were found between the same variables, and between Safety management and Aircraft incidents.

Furthermore, it was revealed that collaboration among the authors in recent years has increased, with $69.5 \%$ of the aforementioned 59 articles published by two or more authors.

There are a total of 13 researchers with a minimum of two and even three published articles, among whom Chen, C.F. (2012, 2014, 2014) and Chen, S.C. (2012, 2014, 2014) stand out for having collaborated three times with one another. However, the remaining 11 authors have collaborated with a wide variety of different authors.

With regard to co-citation, the most frequently cited authors were Liou $(2007,2008)$ and Janic (2000), with 116 and 24 citations, respectively. The greatest co-occurrence observed was between authors Liou and Huang $(\mathrm{n}=13)$ and Liou and Tsai $(\mathrm{n}=13)$.

Finally, it is believed that the study conducted may promote the view that operational safety contributes to business management in the air transport sector. It should be stressed that the SLR carried out offers an opportunity for future lines of research with a more management-oriented focus, as the study has shown that operational safety, as an essential topic in the field of air transport, provides little academic literature related to management.

Other possible lines of future research may, therefore, include the following:

- Analyzing whether safety is profitable for the airlines. In other words, the impact of safety on the profitability of the airlines could be analyzed.

- Studying the extent to which the airlines invest in safety. In other words, what percentage of expenses and/or investment is dedicated to improving safety?

- Analyzing how safety can be measured in air transport. Some sector indicators are already available, such as the JACDEC Safety Index, for example, developed by Jan-Arwed Richter and Christian Wolf (Richter, 2014), which provides information on aircraft accidents and incidents in recent years. 


\section{References}

Acedo, F.J., Barroso, C., Casanueva, C., \& Galán, J.L. (2006). Co-Authorship in Management and Organizational Studies: An Empirical and Network Analysis. Journal of Management Studies, 43(5), 957-983. https://doi.org/10.1111/j.1467-6486.2006.00625.x

AERTEC (2013). Seguridad aeroportuaria: Safety \& Security. Por: José Antonio Poyato Moreira. Available online at: www.aerecsolutions.com. (Last access date: March, 2016).

Air Transport Action Group (ATAG) (2014). Available online at: www.atag.org. (Last access date: March, 2016).

Alves, H., Fernandes, C., \& Raposo, M. (2016). Value co-creation: Concept and contexts of application and study. Journal of Business Research, 69(5), 1626-1633. https://doi.org/10.1016/j.jbusres.2015.10.029

Aviation Safety Network (2016). Available online at: www.aviation-safety.net. (Last access date: March, 2016).

Banco Mundial (2015). Available online at: www.datos.bancomundial.org. (Last access date: March, 2016).

Barnett, A. (2009). Aviation Safety and Security. En: P. Belobaba, A. Odoni \& C. Barnhart (2009). The Global Airline Industry. Chichester (UK): John Wiley and Sons, Ed. https://doi.org/10.1002/9780470744734.ch11

Chang, Y.H., \& Yeh, C.H. (2004). A new airline safety index. Transportation Research Part B: Methodological, 38(4), 369-383. https://doi.org/10.1016/S0191-2615(03)00047-X

Chen, C.F., \& Chen, S.C. (2012). Scale development of safety management system evaluation for the airline industry. Accident Analysis \& Prevention, 47, 177-181. https://doi.org/10.1016/j.aap.2012.01.012

Chen, C.F., \& Chen, S.C. (2014). Investigating the effects of job demands and job resources on cabin crew safety behaviors. Tourism Management, 41, 45-52. https://doi.org/10.1016/j.tourman.2013.08.009

Chen, C.F., \& Chen, S.C. (2014). Measuring the effects of Safety Management System practices, morality leadership and self-efficacy on pilots' safety behaviors: Safety motivation as a mediator. Safety Science, 62, 376-385. https://doi.org/10.1016/j.ssci.2013.09.013

CRD. Centre for Reviews and Dissemination. (2009). Systematic Reviews: CRD's guidance for undertaking reviews in health care. Published by CRD, University of York.

Elsevier (2015). Available online at: www.elsevier.com. (Last access date: March, 2016).

European Aviation Safety Agency (2015). EASA Annual Safety Review 2014. EASA. 
Fox, S. (2014). Safety and Security: The influence of 9/11 to the EU framework for air carriers and aircraft operators. Research in Transportation Economics, 45, 24-33. https://doi.org/10.1016/j.retrec.2014.07.004

Fruchterman, T., \& Reingold, E. (1991). Graph Drawing by Force-directed Placement. Software-practice and experience, 21, 1129-1164. https://doi.org/10.1002/spe.4380211102

Gill, G.K., \& Shergill, G.S. (2004). Perceptions of safety management and safety culture in the aviation industry in New Zealand. Journal of Air Transport Management, 10(4), 231-237. https://doi.org/10.1016/j.jairtraman.2004.02.002

Ginieis, M., Sánchez-Rebull, M.V., \& Campa-Planas, F. (2012a). The academic journal literature on air transport: Analysis using systematic literature review methodology. Journal of Air Transport Management, 19, 31-35. https://doi.org/10.1016/j.jairtraman.2011.12.005

Ginieis, M., Sánchez-Rebull, M.V., \& Campa-Planas, F. (2012b). Los costes en el sector del transporte aéreo. Una revisión de la literatura internacional. Revista Iberoamericana de Contabilidad de Gestión, X(20).

Gmür, M. (2003). Co-citation analysis and the search for invisible colleges: A methodological evaluation. Scientometrics, 57(1), 27-57. https://doi.org/10.1023/A:1023619503005

International Air Transport Association (IATA) (2014). Available online at: www.iata.org. (Last access date: February, 2016).

International Civil Aviation Organization. ICAO. (2015). Safety Report 2015 Edition.

Janic, M. (2000). An assessment of risk and safety in civil aviation. Journal of Air Transport Management, 6(1), 43-50. https://doi.org/10.1016/S0969-6997(99)00021-6

Kalemba, N., \& Campa-Planas, F. (2016). An overview of the Quality Concept in the Air Transportation Business: A systematic Literature Review. In press.

Kelemen, Z. (2003). Latest information technology development in the airline industry. Periodica Polytechnica Ser. Transp. Eng., 31(1-2), 45-52.

Kitchenham, B. (2004). Procedures for performing systematic reviews. Joint Technical Report. Keele University.

Latorella, K.A., \& Prabhu, P.V. (2000). A review of human error in aviation maintenance and inspection. International Journal of Industrial Ergonomics, 26(2), 133-161. https://doi.org/10.1016/S0169$8141(99) 00063-3$

Lee, W.K. (2006). Risk assessment modeling in aviation safety management. Journal of Air Transport Management, 12(5), 267-273. https://doi.org/10.1016/j.jairtraman.2006.07.007 
Liao, M.Y. (2015). Safety Culture in commercial aviation: Differences in perspective between Chinese and Western pilots. Safety Science, 79, 193-205. https://doi.org/10.1016/j.ssci.2015.05.011

Liou, J.J.H., Tzeng, G.-H., \& Chang, H.-C. (2007). Airline safety measurement using a hybrid model. Journal of Air Transport Management, 13(4), 213-220. https://doi.org/10.1016/j.jairtraman.2007.04.008

Liou, J.J.H., Yen, L., \& Tzeng, G.H. (2008). Building an effective safety management system for airlines. Journal of Air Transport Management, 14(1), 20-26. https://doi.org/10.1016/j.jairtraman.2007.10.002

McFadden, K.L., \& Hosmane, B.S. (2001). Operations safety: An assessment of a commercial aviation safety program. Journal of Operations Management, 19, 579-591. https://doi.org/10.1016/S02726963(01)00062-6

Netjasov, F., \& Janic, M. (2008). A review of research on risk and safety modelling in civil aviation. Journal of Air Transport Management, 14(4), 213-220. https://doi.org/10.1016/j.jairtraman.2008.04.008

NodeXL (2013). Available online at: www.nodexl.codeplex.com. (Last access date: March, 2016).

Pacheco, R.R., Fernandes, E., \& Domingos, E.M. (2014). Airport airside safety index. Journal of Air Transport Management, 34, 86-92. https://doi.org/10.1016/j.jairtraman.2013.08.007

Rankin, W., Hibit, R., Allen J., \& Sargent, R. (2000). Development and evaluation of the Maintenance Error Decision Aid (MEDA) process. International Journal of Industrial Ergonomics, 26(2), 261-276. https://doi.org/10.1016/S0169-8141(99)00070-0

Richter, J.A. (2014). The JACDEC Data Base. User Guide Explanations and Definitions. Hamburg: JACDECGbr.

SCImago Journal Rank (2014). Available online at: http://www.scimagoir.com/. (Last access date: March, 2016).

Scopus (2015). Available online at: http://www.scopus.com/. (Last access date: March, 2016).

Seguí-Mas, E., Sarrión-Viñes, F., Tormo-Carbó, G., \& Oltra, V. (2016). Producció científica en el camp de les spin-off acadèmiques: Una anàlisi bibliomètrica. Intangible Capital, 12(1), 246-267.

Shappell, S., Detwiler, C., Holcomb, K., Hackworth, C., Boquet, A., \& Wiegmann, D.A. (2007). Human error and Commercial Aviation Accidents: An Analysis Using the Human Factors Analysis and Classification System. Human Factors, 49(2), 227-242. https://doi.org/10.1518/001872007X312469

Taylor, J.C. (2000). The evolution and effectiveness of Maintenance Resource Management (MRM). International Journal of Industrial Ergonomics, 26(2), 201-215. https://doi.org/10.1016/S0169-8141(99)00066-9 
Webster, J., \& Watson, R. (2002). Analyzing the past to prepare for the future: Writing a literature review. MIS Quarterly, 26(2), 13-23.

\section{Versión en español}

Título: La seguridad operacional como elemento de gestión en el sector del transporte aéreo: Una revisión sistemática de literatura

\section{Resumen}

Objeto: El objetivo principal del presente estudio es llevar a cabo una revisión de literatura sobre la aportación de la seguridad operacional (safety) en el sector de transporte aéreo en base a la literatura académica internacional existente en el ámbito de las ciencias sociales. Además, se trata de analizar y comprobarla relación entre los conceptos relacionados con la seguridad operacional (co-ocurrencia), el vínculo entre los diferentes autores (coautoría) y sus correspondientes citas (co-citación).

Diseño/metodología/enfoque: Para lograr los objetivos establecidos, se ha realizado una revisión sistemática de literatura (SLR) a través de la base de datos Scopus entre los años 1990 y 2016, identificando los artículos académicos internacionales correspondiente sal tema de investigación del presente estudio.

Aportaciones y resultados: Se ha comprobado, por un lado, que la seguridad operacional en el sector de transporte aéreo es un campo de creciente interés, ya que el número de artículos se ha incrementado considerablemente en los últimos años, mostrando, por lo tanto, la importancia adquirida del tema estudiado a lo largo de tiempo. Pero, por otro lado,también mencionar que el número total de artículos referente al tema es en valor absoluto bajo.

Los resultados del análisis de co-ocurrencia muestran que la variable que mayor relevancia obtiene referente a la seguridad operacional es la gestión de la seguridad operacional, mientras que el vínculo más fuerte se observa entre la gestión de la seguridad operacional y los accidentes de aviación, hecho a priori previsible.

Originalidad / Valor añadido: El enfoque utilizado permite obtener una mejor visión sobre la aportación académica en relación a la seguridad operacional y cuál es el vínculo entre las 
diversas variables analizadas acerca del concepto investigado, como también demuestra el creciente interés mostrado en este ámbito.

Palabras clave: Seguridad operacional, Transporte aéreo, Aerolíneas, Calidad, Rentabilidad, Revisión sistemática de literatura

Códigos JEL: J28, L93

\section{Introducción}

El sector del transporte aéreo es un proveedor esencial de una amplia gama de servicios, siendo una industria de rápido crecimiento que se enfrenta a un gran número de retos, creando beneficios, debido a los numerosos acontecimientos y tendencias que le influyen, tanto sociales como también económicos (IATA, 2014; ATAG, 2014).

Dentro de la gran variedad de circunstancias que influyen en el sector de transporte aéreo, un elemento clave es ofrecer operaciones con una alta seguridad y eficiencia a los pasajeros a nivel global (ICAO, 2015), como también lo es garantizar la seguridad de las personas que operan en torno a las aeronaves, así como la propia seguridad de las mismas (AERTEC, 2013).

El transporte aéreo destaca, frente a otros medios alternativos, por factores como su velocidad, coste, eficiencia, comodidad y flexibilidad (Kelemen, 2003; ATAG, 2014), además de que sus condiciones de seguridad son muchas más altas en relación a las de otros tipos de transporte, sea por carretera, ferrocarril, etc. (Pacheco, Fernandes \& Domingos, 2014).

La mejora del estándar de seguridad siempre ha sido una de las principales prioridades del sector, sino la primera (Liou, Yen \& Tzeng , 2008). Sin duda, es un concepto que juega un rol imprescindible y su mejora se ha convertido en un tema de interés creciente en el campo de gestión de operaciones (McFadden \& Hosmane, 2001), además de que la industria del transporte aéreo es conocida por sus esfuerzos y el reto incesante de querer destacar siempre por su alto nivel de seguridad y, por lo tanto, disminuir el número de accidentes e incidentes (Shappell, Detwiler, Holcomb, Hackworth, Boquet \& Wiegmann, 2007; Liao, 2015). 
Mientras que el número de pasajeros del sector va aumentando continuamente, el número de pasajeros víctimas de accidentes va disminuyendo en valor absoluto y, por lo tanto, en mayor medida, en valor relativo (Aviation Safety Network, 2016; ICAO, 2015).

No obstante, y debido a la dificultad de definir los aspectos que se incluyen en el marco de la seguridad operativa, el objetivo principal del estudio es obtener una amplia visión sobre las aportaciones realizadas en la literatura sobre la seguridad operacional en el transporte aéreo, su evolución en el tiempo y ver cuáles son los conceptos que están más relacionados a ella (co-ocurrencia).

Para conseguir dicho objetivo, se ha examinado y recopilado la información necesaria a través de una revisión sistemática de literatura haciendo uso de la base de datos Scopus.

Otros objetivos más específicos, teniendo en cuenta en cada momento el presente tema de investigación, son los siguientes:

- Ver cuál es la evolución de las publicaciones académicas relacionadas con la seguridad operacional en el transporte aéreo durante el periodo 1990-2016 (entendiendo el año 2016 como la revisión realizada antes del 29 de febrero de dicho año).

- Obtener una visión general sobre las revistas principales que tratan el tema de investigación.

- Identificar cuáles son los artículos académicos más citados y sus correspondientes investigadores.

- Ver la relación entre los diferentes investigadores (coautoría).

- Ver la co-citación entre los documentos incluidos en el presente estudio.

- Mostrar y analizar la procedencia de los autores de los artículos relacionados.

Por lo tanto, la principal contribución de este artículo es describir y dar a conocer que se ha dicho sobre la seguridad operacional en el sector de transporte aéreo en las últimas décadas, cuales son los autores que más destacan y ver cuál es la relación que existe entre las variables establecidas y el concepto de seguridad operacional.

El presente documento se ha estructurado de la siguiente manera. Primero de todo se presenta el campo de interés y el tema de investigación, es decir, la seguridad operacional en el transporte aéreo. En segundo lugar, se describe la metodología utilizada para llevar a cabo la investigación. La tercera sección 
presenta los resultados obtenidos, mientras que en la última parte se muestran las principales conclusiones obtenidas.

\section{Marco conceptual y evolución de la seguridad operacional}

En este apartado se pretende analizar el concepto de seguridad operacional, así como también mostrar la evolución de dicho concepto en el tiempo.

\subsection{Dualidad de interpretación}

Antes de definir la seguridad, es necesario comentar, que un problema que se puede encontrar en el momento de utilizar el concepto de seguridad en el ámbito de transporte aéreo, es su dualidad de interpretación, ya que la palabra tiene un significado ambiguo.

Un concepto es la seguridad operacional (safety), que hace referencia a conceptos relacionados con los incidentes y accidentes en el transporte aéreo (AERTEC, 2013), mientras que otro aspecto es la seguridad física (security), como son por ejemplo "actos criminales e interferencias ilícitas" (AERTEC, 2013), que pueden afectar a la protección tanto de pasajeros, como también de los empleados en tierra y las tripulaciones, entre otros. Por lo tanto, el security puede afectar, en mayor o menor medida también a la seguridad operacional, o safety.

Tanto la seguridad operacional como la seguridad física, siempre han sido dos objetivos claves y un gran reto en el sector del transporte aéreo (Fox, 2014), y más después de los acontecimientos de septiembre 2011 en los Estados Unidos. Según Barnett (2009), los dos factores que los pasajeros más relacionan con el hecho de viajar de forma segura es primero, evitar accidentes de aviones; y, en segundo lugar, la prevención de sucesos criminales y terroristas.

\subsection{Seguridad operacional}

Según AERTEC (2013), la seguridad operacional funciona cuando disminuye la posibilidad de accidentes e incidentes o lesiones a los pasajeros, bienes o empleados gracias al continuo proceso de análisis y gestión tanto de peligros como riesgos. 
La Organización de Aviación Civil Internacional (ICAO) define a la seguridad operacional de manera similar, como un estado en el que la posibilidad de daño a personas o propiedades es reducida y se intenta mantener baja y controlada a través de un continuo análisis de riesgos, entre otros.

Es decir, la seguridad operacional hace referencia al hecho de disminuir a lo mínimo posible tanto los accidentes como también los incidentes. De acuerdo con AERTEC (2013) hay que tener en cuenta tres criterios para la definición de la seguridad operacional. En primer lugar, cómo evaluar y detectar riesgos para mantenerlos a un nivel bajo aceptable; en segundo lugar, investigar incidentes para poder tomar decisiones acertadas y preventivas, y, finalmente, definir variables e indicadores de seguridad que permitan medir y hacer un seguimiento del nivel de seguridad.

\subsection{Evolución de la seguridad operacional en los últimos años}

Como anteriormente se ha mencionado, el número de pasajeros ha ido aumentando continuamente, mientras que el número de accidentes mortales ha disminuido significativamente en las últimas décadas, tal como se muestra en la Figura 1.

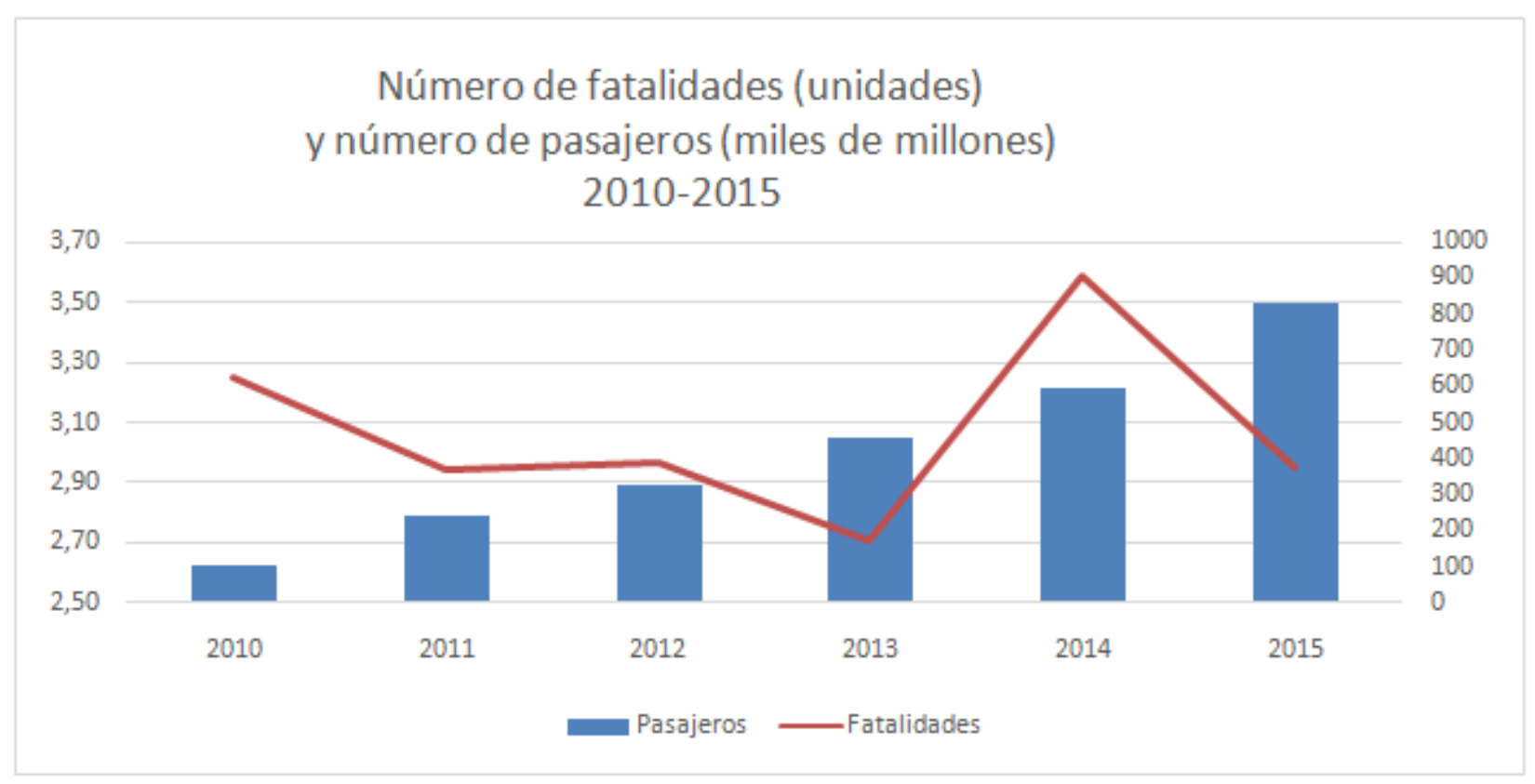

Figura 1. Número de accidentes fatales y número de pasajeros 2010-2015 (Elaboración propia a partir de datos del Banco Mundial (2015) y ICAO (2015)) 
La Figura 1 muestra el crecimiento constante del número de los pasajeros que en 2015 llega a ser de 3.5 miles de millones de pasajeros, suponiendo un incremento del 8.9\% respecto al año 2014.

Según la European Aviation Safety Agency (EASA, 2015), el número de accidentes fatales en el año 2014 ha estado por debajo de la media total de los últimos 10 años (2004-2013), a pesar del hecho de que el 2014 (ver Figura 1) fue un año que destacó por su número de víctimas mortales (n=904).

El año 2014 incluye dos accidentes singulares como son los del vuelo 370 de Malaysia Airlines (desaparecido en marzo de 2014, y aun sin evidencias de su causa), como también el vuelo 17 de la misma compañía en Julio 2014 que fue víctima de un atentado al sobrevolar Ucrania.

\section{Metodología}

La metodología seguida en el presente estudio ha sido la siguiente. En primer lugar, se ha realizado una revisión sistemática de la literatura (systematic literaturere view, SLR en adelante), haciendo uso de la base de datos bibliográfica, Scopus, base de datos que ofrece una amplia visión sobre artículos académicos internacionales junto a una gran base de resúmenes y citas (Elsevier, 2015).

La metodología de la revisión sistemática de literatura es una herramienta esencial de cualquier proyecto en el ámbito académico, ya que ayuda a incrementar los conocimientos necesarios de los investigadores sobre un tema específico (Webster \& Watson, 2002). Además, tiene la ventaja de proveer información rigurosa, exhaustiva, fiable y no sesgada (Kitchenham, 2004).

Kitchenham (2004) menciona además dos aspectos fundamentales que hacen necesaria la SLR, como el de identificar los gaps para proponer futuras líneas de investigación y también presentar un marco de antecedentes.

En la mayoría de los casos, la SLR se ha utilizado en el ámbito de la salud (CRD, 2009), y en otras disciplinas como las políticas públicas, pero también ha sido aplicada en relación al sector de transporte aéreo (Ginieis, Sánchez-Rebull \& Campa-Planas, 2012a-b).

Todo ello demuestra, que la SLR es una herramienta muy útil para la evaluación y el análisis de la información disponible y su posterior interpretación y respuesta acerca de la pregunta de investigación a estudiar (Kitchenham, 2004). 
La SLR del presente estudio incluye el periodo de 1990 hasta febrero 2016, abarcando un amplio periodo de tiempo, lo cual permite conseguir una visión general sobre la evolución del concepto de seguridad operacional en el transporte aéreo.

En segundo lugar, para el análisis de la coautoría, co-citación entre los diferentes artículos, así como también para la comparación de variables (co-ocurrencia) referentes a la seguridad operacional, se ha hecho uso del programa NodeXL Template for Microsoft Excel 2007, el cual facilita el aprendizaje de conceptos y permite elaborar un análisis de redes que se visualizan de tal manera que sea fácil ver la relación existente entre las diferentes variables (NodeXL, 2013).

\subsection{Identificación de palabras clave y muestreo de artículos}

Para la identificación de las publicaciones relacionadas con el presente estudio se han establecido diversas combinaciones con un total de 9 palabras claves (tres palabras clave primarias y seis palabras claves secundarias), tal como se muestra a continuación:

- Safety AND Airlines OR Air Transportation AND Profitability

- Safety AND Airlines OR Air Transportation AND Quality

- Safety AND Airlines OR Air Transportation AND Cost Maintenance

- Safety AND Airlines OR Air Transportation AND Management

- Safety AND Airlines OR Air Transportation AND Performance

- Safety AND Airlines OR Air Transportation AND Success

Como se puede observar en la Tabla 1, considerando las diferentes combinaciones de palabras clave primarias y secundarias, el total de artículos encontrados en la base de datos Scopus dentro del ámbito de las ciencias sociales después de una primera búsqueda ha sido de 1,021, un número en el que están también incluidos comunicaciones de congresos y capítulos de libros, los cuales a posteriori fueron eliminados para la revisión final. 


\begin{tabular}{|c|c|}
\hline Combinación palabras clave & $\begin{array}{l}\text { Cantidad de artículos } \\
\text { encontrados }\end{array}$ \\
\hline Safety AND Airlines AND Profitability & 17 \\
\hline Safety AND Air Transportation AND Profitability & 9 \\
\hline Safety AND Airlines AND Quality & 62 \\
\hline Safety AND Air Transportation AND Quality & 126 \\
\hline Safety AND Airlines AND Cost Maintenance & 15 \\
\hline Safety AND Air Transportation AND Cost Maintenance & 8 \\
\hline Safety AND Airlines AND Management & 193 \\
\hline Safety AND Air Transportation AND Management & 299 \\
\hline Safety AND Airlines AND Performance & 105 \\
\hline Safety AND Air Transportation AND Performance & 147 \\
\hline Safety AND Airlines AND Success & 23 \\
\hline Safety AND Air Transportation AND Success & 17 \\
\hline Total Artículos & 1,021 \\
\hline
\end{tabular}

Tabla 1. Resultados de búsqueda total en la base de datos Scopus

Para la búsqueda de dichas palabras y combinaciones, se utilizaron las 9 palabras clave en su denominación en idioma inglés, idioma en el que está indexada la base de datos Scopus.

El criterio de búsqueda y el posterior filtro de artículos a partir de la eliminación de duplicados se ha basado en que mínimo una de las palabras clave debía mostrarse o en el título, en el resumen del artículo, o en las keywords establecidos por cada uno de los autores.

De acuerdo a este procedimiento, la base bibliográfica final ha estado compuesta por 59 artículos académicos internacionales, en base a los cuales se ha llevado a cabo el estudio presente, tal como se muestra en la Tabla 2.

\begin{tabular}{|l|r|r|}
\hline \multicolumn{1}{|c|}{ Filtro de artículos } & $\begin{array}{c}\text { Artículos } \\
\text { eliminados }\end{array}$ & $\begin{array}{c}\text { Total de artículos } \\
\text { considerados para la SLR }\end{array}$ \\
\hline Búsqueda total principal inicial & $(405)$ & 1,021 \\
\hline Eliminación de duplicados & $(557)$ & 616 \\
\hline Eliminación de artículos en base al criterio de búsqueda & $\mathbf{5 9}$ \\
\hline
\end{tabular}

Tabla 2. Muestra final de artículos incluidos en la revisión de literatura

\subsection{Codificación de variables acerca de la seguridad operacional}

Después de una revisión y lectura de los referidos 59 artículos sobre la seguridad operacional y con la colaboración de un panel de expertos, se determinaron 11 variables clave que se derivaban de la lectura de los mismos. Las variables detectadas han sido las siguientes: 
1. Aircraft accidents: Relacionado con accidentes de avión, colisiones, entre otros; sucesos que generan la muerte o lesiones graves de las personas, y donde el avión recibe un daño sustancial.

2. Aircraft incidents: Un suceso distinto de un accidente operacional, el cual está relacionado con una operación y utilización de una aeronave que pueda afectar la seguridad operacional (safety).

3. Aircraft relate dissues: Aspectos relacionados con el avión, es decir, tipo de avión, edad de la flota, entre otros.

4. Customer relate dissues: Incluye aspectos como la satisfacción del cliente, percepción, comportamiento, humor, entre otros.

5. Human factors: Esta variable abarca tanto errores humanos, como también la gestión de recursos humanos (HRM), entre otros.

6. Maintenance: El mantenimiento del avión está relacionado con aspectos como la reparación, inspección, revisión general, mecanismos de fallo, entre otros.

7. Safety culture: Incluye todo relacionado a la cultura hacia la seguridad operacional, como el compromiso y dedicación en cuanto a la seguridad, la definición de obligaciones y responsabilidades de los empleados, entre otros.

8. Safety management: Variable de la gestión de seguridad operacional que incluye aspectos como sistemas y programas de la gestión de seguridad operacional, así como la gestión relacionada con los riesgos y su análisis.

9. Safety performance: Aspectos vinculados a la estabilidad financiera, rentabilidad económica y financiera, salud financiera de la compañía aérea, etc.

10. Security: Incluye todo lo relacionado con la seguridad física, como la protección de pasajeros, personal en tierra, tripulaciones, el propio avión, etc.

11. Technical flightcrew: La variable tripulación técnica de vuelo abarca aspectos como las habilidades comunicativas de los empleados, la formación, así como también la experiencia del piloto (total de horas de vuelo), entre otros. 
Todas las variables han sido necesarias para poder establecer y demostrar posteriormente la relación existente entre los diferentes conceptos incluidos (co-ocurrencia) durante la SLR y por lo tanto ver también cuales son los temas que fueron tratados con mayor frecuencia durante el período analizado.

\section{Resultados descriptivos}

Este apartado muestra los resultados descriptivos obtenidos a partir de los 59 artículos de la base de datos Scopus, junto a los 134 autores incluidos en el estudio y resultantes de dichos artículos, teniendo en cuenta el periodo de tiempo de 1990-febrero 2016 cubierto por el mismo.

\subsection{Evolución de artículos académicos sobre la seguridad operacional}

La Figura 2 muestra la evolución temporal de la selección final de artículos académicos internacionales $(n=59)$ los cuales han sido elegidos después de laSLR exhaustiva realizada.

Sobre todo, en el periodo de 2012-2015, el número de publicaciones ha aumentado significativamente, suponiendo un $42.37 \%$ sobre el total analizado, resultado que refleja la creciente importancia del tema estudiado durante los últimos años.

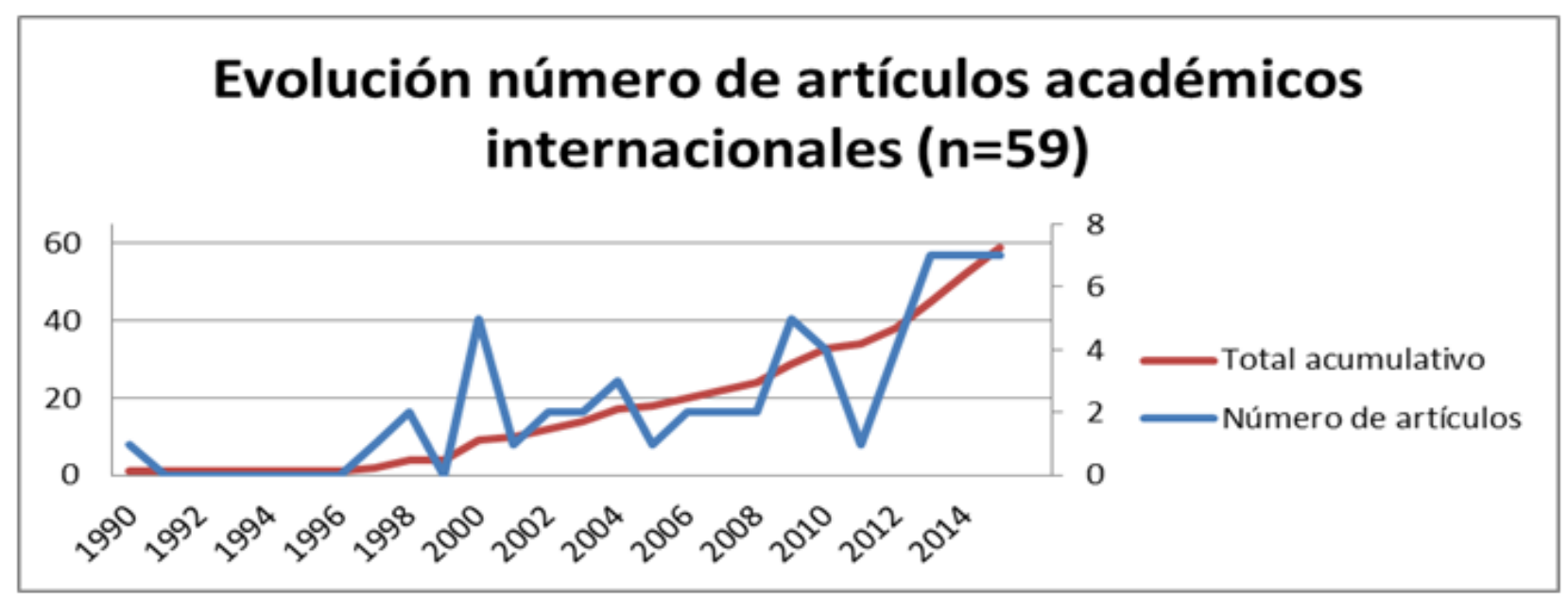

Figura 2. Evolución del número de artículos académicos internacionales durante los años 1990-2016 
Como también se puede observar, durante los años 1990-1997 el número de artículos publicados es muy bajo e incluso nulo. Es a partir del año 2000 y especialmente desde el año 2006 cuando el tema empieza a crecer como tema de investigación, aunque resaltar que, en general, el número total de artículos en valor absoluto es muy bajo en relación a otros estudios realizados en el ámbito de transporte aéreo (Ginieis, Sánchez-Rebull \& Campa-Planas, 2012a-b; Kalemba \& Campa-Planas, 2016).

\subsection{Revistas más productivas y más citadas}

En este apartado se analiza cuáles son las revistas más productivas y más citadas en este estudio en referencia al tema tratado en esta SLR, teniendo en cuenta los 59 artículos obtenidos de la revisión de literatura sistemática y su ranking correspondiente.

\begin{tabular}{|r|l|r|r|r|c|}
\cline { 2 - 6 } \multicolumn{1}{c|}{ Nombre de la revista } & $\begin{array}{c}\text { No de artículos } \\
\text { en el estudio }\end{array}$ & $\mathbf{N}^{\circ}$ de citas & $\begin{array}{c}\text { Factor de } \\
\text { impacto a 5 } \\
\text { años }\end{array}$ & Cuartil \\
\hline $\mathbf{1}$ & Journal of Air Transport Management & 16 & 463 & 1.328 & Q1/Q2 \\
\hline $\mathbf{2}$ & Safety Science & 14 & 98 & 2.210 & Q1 \\
\hline $\mathbf{3}$ & $\begin{array}{l}\text { International Journal of Industrial } \\
\text { Ergonomics }\end{array}$ & 3 & 110 & 2.366 & Q2 \\
\hline $\mathbf{4}$ & Accident Analysis \& Prevention & 2 & 27 & 2.699 & Q1 \\
\hline $\mathbf{5}$ & Applied Ergonomics & 2 & 2.143 & Q1 \\
\hline $\mathbf{6}$ & Quality Progress & 2 & 2 & ND & Q4 \\
\hline $\mathbf{7}$ & Research in Transportation Economics & 2 & 2 & ND & Q1/Q2 \\
\hline $\mathbf{8}$ & $\begin{array}{l}\text { Transportation Research Part E: Logistics } \\
\text { and Transportation Review }\end{array}$ & 28 & 3.513 & Q1 \\
\hline
\end{tabular}

Tabla 3. Revistas más productivas y citadas en relación a la revisión sistemática de literatura

La Tabla 3 muestra las revistas más productivas y que tengan como mínimo 2 ó más artículos incluidos en el presente estudio ( $n=8)$, como también su factor de impacto a 5 años y el cuartil al que corresponde cada una de las revistas dependiendo de su categoría.

Las primeras dos revistas, el Journal of Air Transport Management (Reino Unido) y Safety Science (Países Bajos) representan más del 50\% de las publicaciones realizadas sobre el total de los artículos incluidos en el estudio (30 de 59 artículos), y por lo tanto, se puede ver que los artículos están concentrados en un pequeño número de revistas. 
El Journal of Air Transport Management ( $\mathrm{n}=16)$ está con 463 citas en primera posición, siendo además la revista más específica referente al transporte aéreo.

También mencionar que al mismo tiempo es la revista con menor factor de impacto a 5 años, siendo una revista de primer/segundo cuartil en las subcategorías de derecho, management y transporte (SCImago Journal \& Country Rank, 2014).

Por otro lado, la revista Safety Science se encuentra en el primer cuartil en las subcategorías de salud y seguridad operacional (SCImago Journal \& Country Rank, 2014).

\subsection{Artículos más citados}

La Tabla 4 ofrece información sobre los artículos más citados, teniendo en cuenta los autores, el título, así como también el año de publicación y el número total de citas obtenidas desde su publicación.

\begin{tabular}{|r|l|r|r|r|}
\cline { 2 - 5 } \multicolumn{1}{c|}{ Autores } & \multicolumn{1}{c|}{ Título } & \multicolumn{1}{c|}{ Año } & \multicolumn{1}{c|}{ Citas } \\
\hline $\mathbf{1}$ & Liou, J.J.H., Tzeng, G.H., Chang, H.C. & Airline safety measurement using a hybrid model & 2007 & 164 \\
\hline $\mathbf{2}$ & Liou, J.J.H., Yen, L., Tzeng, G.H. & Building an effective safety management system for airlines & 2008 & 83 \\
\hline $\mathbf{3}$ & Janic, M. & An assessment of risk and safety in civil aviation & 2000 & 61 \\
\hline $\mathbf{4}$ & Latorella, K.A., Prabhu, P.V. & $\begin{array}{l}\text { A review of human error in aviation maintenance and } \\
\text { inspection }\end{array}$ & 2000 & 55 \\
\hline $\mathbf{5}$ & Chang, Y.H., Yeh, C.H. & A new airline safety index & 2004 & 37 \\
\hline $\mathbf{6}$ & Netjasov, F., Janic, M. & $\begin{array}{l}\text { A review of research on risk and safety modelling in civil } \\
\text { aviation }\end{array}$ & 2008 & 34 \\
\hline $\mathbf{7}$ & $\begin{array}{l}\text { Rankin, W., Hibit, R., Allen, J., } \\
\text { Sargent, R. }\end{array}$ & $\begin{array}{l}\text { Development and evaluation of the Maintenance Error } \\
\text { Decision Aid (MEDA) process }\end{array}$ & 2000 & 33 \\
\hline $\mathbf{8}$ & Gill, G.K., Shergill, G.S. & $\begin{array}{l}\text { Perceptions of safety management and safety culture in the } \\
\text { aviation industry in New Zealand }\end{array}$ & 2004 & 33 \\
\hline $\mathbf{9}$ & Lee, W.K. & Risk assessment modeling in aviation safety management & 2006 & 30 \\
\hline $\mathbf{1 0}$ & Taylor, J.C. & $\begin{array}{l}\text { The evolution and effectiveness of Maintenance Resource } \\
\text { Management (MRM) }\end{array}$ & 2000 & 22 \\
\hline
\end{tabular}

Tabla 4. Artículos académicos más citados en base a la revisión sistemática de literatura

El artículo más citado es de Liou, Tzeng and Chang (2007) con el título "Airline safety measurement using a bybrid model', habiendo obtenido un total de 164 citas, seguido por un artículo del mismo autor Liou et al. (2008) titulado "Building an effective safety management system for Airlines", habiendo alcanzado un total de 83 citas. Ambos artículos han sido publicados en el Journal of Air Transport Management, ya comentado anteriormente. 


\subsection{Relación de autores (coautoría)}

Para poder demostrar la colaboración entre los diferentes autores establecida en los artículos seleccionados durante la SLR, se ha creado un mapa de coautoría.

Durante la evolución de tiempo considerado en el estudio, los trabajos científicos cada vez más han estado co-autorizados y siguiendo dicha tendencia el fenómeno de coautoría ha ganado mayor interés en los últimos años (Acedo, Barroso, Casanueva \& Galán, 2006).

Los 59 artículos académicos que han sido seleccionados, han sido escritos por un total de 134 autores, de los cuales 13 han contribuido a dos e incluso tres artículos. Los dos autores más productivos han sido Chen, C.F. $(2012,2014,2014)$ y Chen, S.C. (2012, 2014, 2014), habiendo colaborado ambos autores en las tres ocasiones entre ellos.

En la Figura 3 se observa de forma gráfica dicha información sobre la co-autoría. 

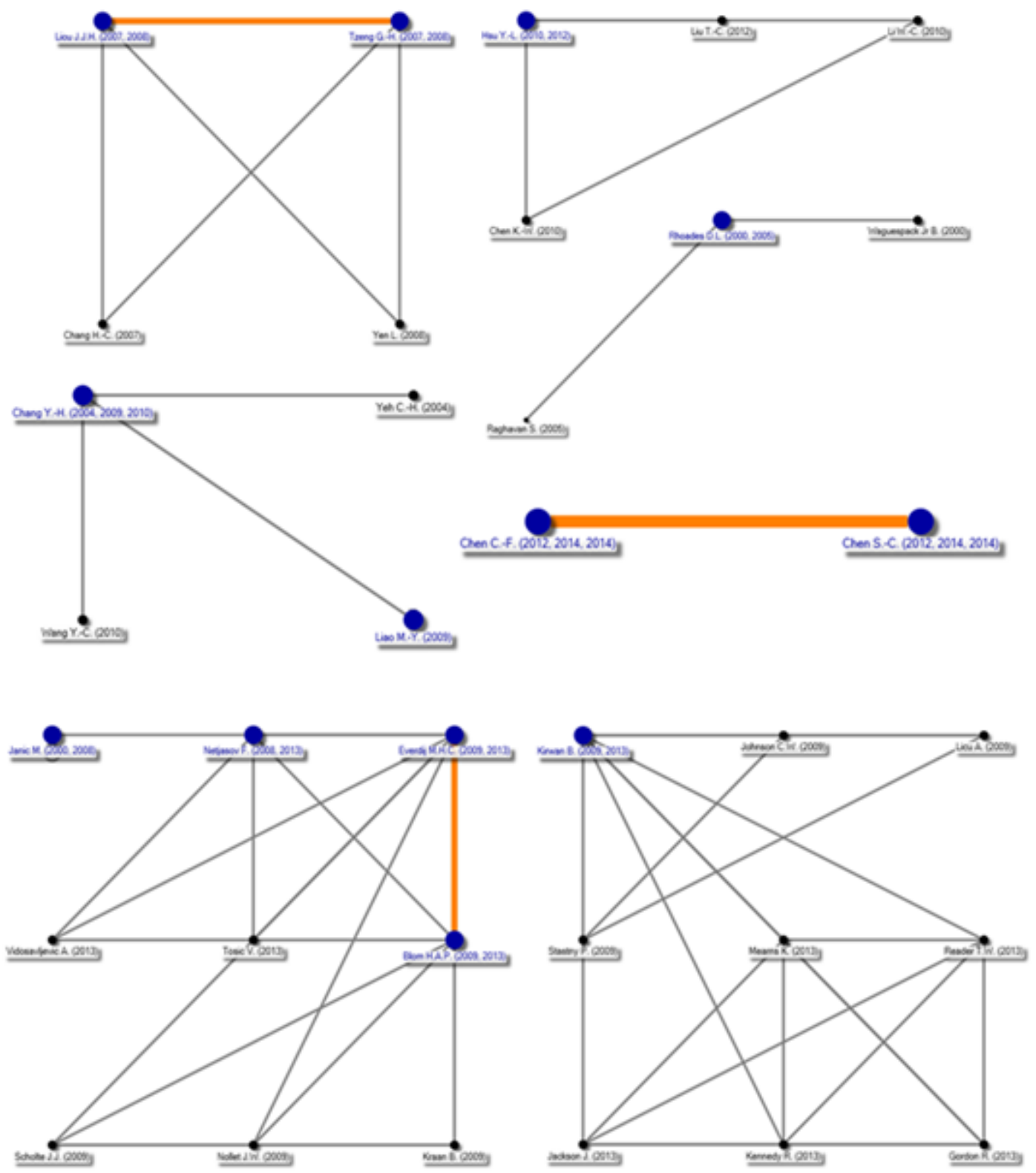

Figura 3. Coautoría entre los autores (Elaboración propia a través de NodeXL)

Comentar que en el caso de un 32.20\% delos 59 artículos han sido realizados por dos autores $(\mathrm{n}=19)$, un $30.51 \%$ por un solo autor y un $23.73 \%$ por tres autores. El $13.56 \%$ restante pertenece a un número de 4 a 6 autores. 


\subsection{Relación entre artículos citadosco-citación}

El análisis de co-citación ha llegado a ser un método necesario y dominante para trabajos científicos en los últimos años y ha sido aplicado ya en una multitud de estudios (Seguí-Mas, Sarrión-Viñes, TormoCarbó \& Oltra, 2016; Alves, Fernandes \& Raposo, 2016). Es una herramienta que ayuda a analizar diferentes grupos de investigadores, a ver sus publicaciones y campos de aplicación (Alves et al., 2016), así como también a observar similitudes de contenido de los autores citados (Gmür, 2003).

En la Figura 4 se puede ver un mapa de co-citación de los autores de los artículos con mayor número de citas en relación a la seguridad operacional, teniendo en cuenta el criterio que el número de citas sea mayor o igual a $50(n=4)$. Para todos los casos se ha incluido solamente el primer autor de cada artículo y, además,se han eliminado posteriormente todos los autores con menos de dos citas para poder obtener lo tanto una mejor visión sobre las co-citaciones entre los autores.

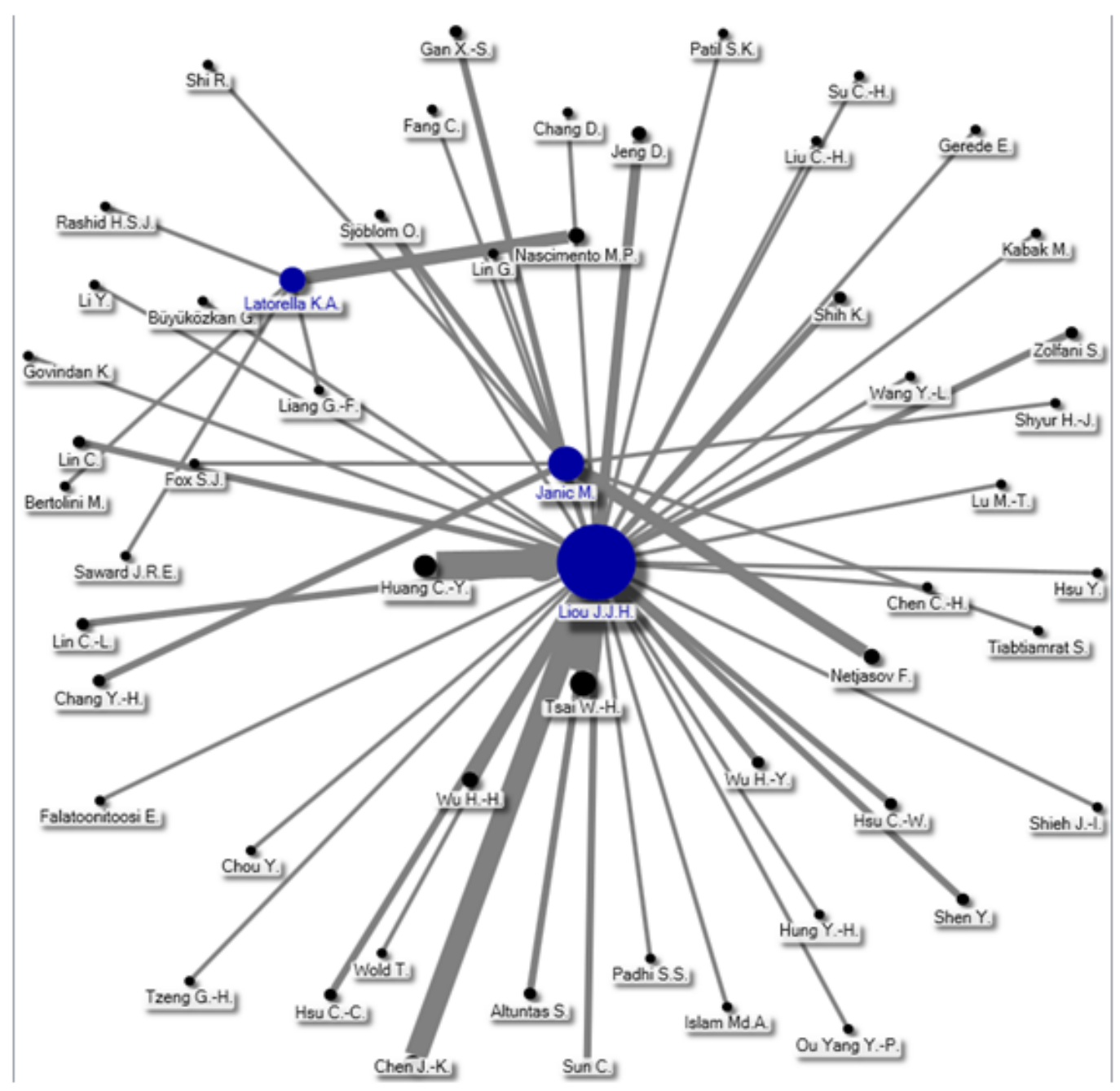

Figura 4. Co-citación entre autores (Elaboración propia a través de NodeXL) 
Los autores más citados fueron Liou $(2007,2008)$ y Janic (2000) con 116 y 24 citas, respectivamente. La mayor co-ocurrencia de citas existe entre Liou y Huang $(n=13)$ y Liou y Tsai $(n=13)$.

\subsection{Procedencia de autores}

Para poder observarla distribución espacial y estudiar, donde más se ha tratado el presente tema de investigación, se ha hecho un análisis sobre cuál es la procedencia de cada uno de los autores. En las Figuras 5 y 6 se puede contemplar los 17 países donde se ha estudiado la temática de la seguridad operacional en el transporte aéreo.

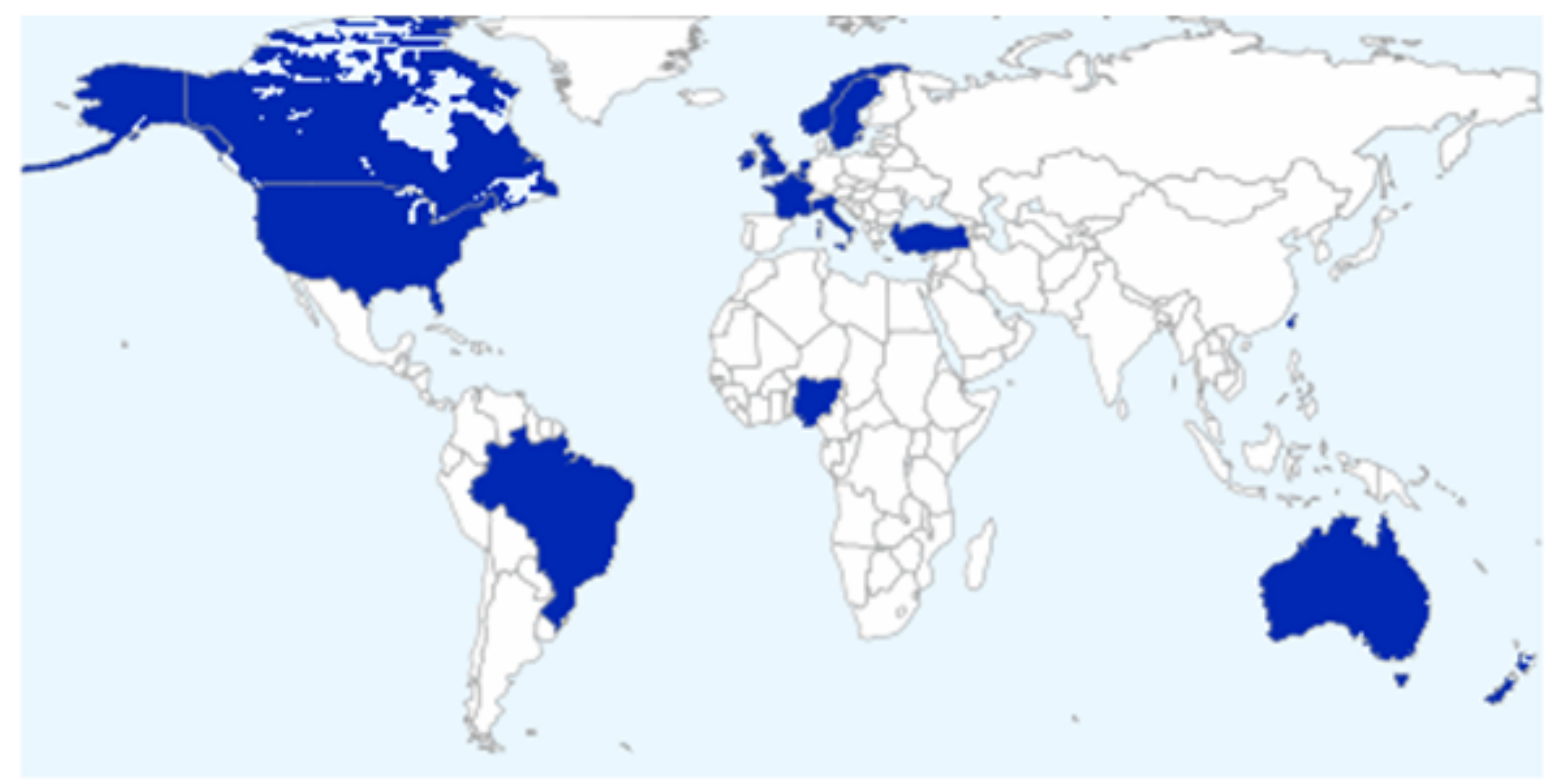

Figura 5. Procedencia de autores por países

Entre los países incluidos predominan sobre todo Estados Unidos y Taiwán, suponiendo un 24.6\% (33 autores) y 23.95\% (32 autores), respectivamente, sobre el total de los 134 autores de los artículos que abarcan la revisión de literatura realizada.

Los países pertenecientes a la Unión Europea que con mayor proporción de autores destacan, son el Reino Unido (10.4\%) y Holanda (6.0\%). 


\begin{tabular}{|l|c|c|}
\hline Procedencia de autores & Número de autores & Porcentaje/total \\
\hline Estados Unidos & 33 & $24,6 \%$ \\
\hline Taiwan & 32 & $23,9 \%$ \\
\hline Reino Unido & 14 & $10,4 \%$ \\
\hline Australia & 13 & $9,7 \%$ \\
\hline Noruega & 9 & $6,7 \%$ \\
\hline Holanda & 8 & $6,0 \%$ \\
\hline Nueva Zelanda & 5 & $3,7 \%$ \\
\hline Italia & 4 & $3,0 \%$ \\
\hline Serbia & 4 & $3,0 \%$ \\
\hline Brasil & 3 & $2,2 \%$ \\
\hline Belgica & 2 & $1,5 \%$ \\
\hline Canada & 2 & $1,5 \%$ \\
\hline Francia & 1 & $0,7 \%$ \\
\hline Irlanda & 1 & $0,7 \%$ \\
\hline Nigeria & 1 & $0,7 \%$ \\
\hline Suecia & 1 & $0,7 \%$ \\
\hline Turquía & 1 & $0,7 \%$ \\
\hline & & \\
\hline \multicolumn{1}{|c|}{ Total de autores } & $\mathbf{1 3 4}$ & \\
\hline
\end{tabular}

Figura 6. Procedencia de autores por países

\subsection{Análisis de red de variables relacionados a la seguridad operacional}

Para poder demostrar la relación entre los diferentes conceptos que van unidos a la seguridad operacional, tratados en la literatura básica, se ha llevado a cabo un análisis de co-ocurrencia de los aspectos clave.

Se ha creado un mapa de co-ocurrencias (ver Figura 7) con la herramienta NodeXl (NodeXl, 2013) teniendo en cuenta las once variables establecidos anteriormente expuestos en base a los 59 artículos incluidos en la SLR.

La referida figura se ha representado a través del diseño Fruchterman y Reingold (1991), basado por un lado en aristas, las cuales muestran la importancia como también la frecuencia de co-ocurrencia entre una u otra variable; y, por otro lado, el volumen de cada uno de los vértices, los cuales representan la relevancia de cada una de las variables. 


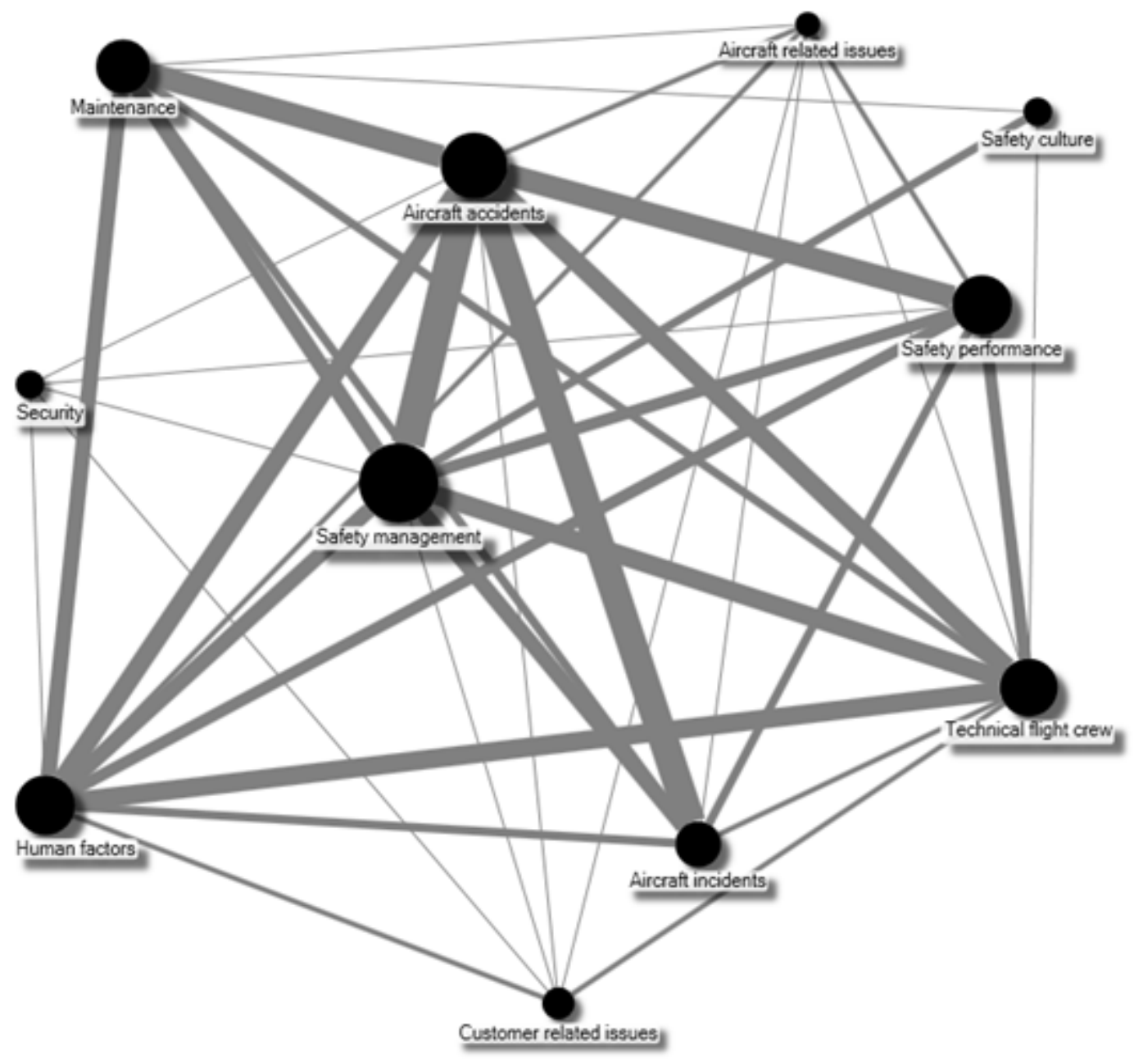

Figura 7. Relación entre las variables establecidas en referencia a la seguridad operacional (Elaboración propia a través de NodeXL)

Como bien se puede observar en la Figura 7, el vértice con mayor peso, es decir, el concepto más utilizado en relación a la seguridad operacional en la literatura académica internacional existente es la gestión de la seguridad operacional (Safety management) $(\mathrm{n}=30)$, seguido por los accidentes de avión (Aircraft accidents) $(\mathrm{n}=22)$, mientras que el vínculo más fuerte se muestra entre las variables de gestión de seguridad operacional (Safety management) y los accidentes de avión (Aircraft accidents), así como entre la gestión de seguridad operacional (Safety management) y los incidentes de avión (Aircraft incidents). La Figura 7 muestra también que otras variables que más se utilizan en relación al concepto de la seguridad operacional son factores humanos (Human factors), rendimiento de seguridad (Safety performance) y la tripulación técnica de vuelo (Technical flightcrew). 


\section{Conclusiones}

A pesar de que la seguridad operacional (safety) es un elemento clave en el sector de transporte aéreo, mencionar, que no existe ningún artículo de revisión de literatura específica en el sector sobre la aportación del concepto estudiado en este artículo.

Por lo tanto, el estudio ha tratado de cubrir el referido gap y llevar a cabo una revisión sistemática de literatura (SLR) a través de la base de datos Scopus, revisión que permitiera la identificación de artículos académicos internacionales correspondientes al tema de investigación propuesto.

Se han examinado cuales son las revistas y artículos más citados, además de ver el grado de coocurrencia entre las variables establecidas por los autores con la ayuda de un panel de expertos, y que estuvieran relacionadas con la seguridad operacional, así como también ofrecer una visión sobre la coautoría y las co-citaciones entre los diferentes autores. Partiendo de un total de 1,021 artículos, una vez depurados los artículos seleccionados se ha analizado una muestra de 59 artículos publicados entre los años 1990 y febrero 2016.

Como primera conclusión comentar que el tema de investigación es un tema de creciente interés, aunque el número total de artículos en valor absoluto sigue siendo muy bajo.

La mayoría de los artículos obtenidos después de una primera búsqueda han estado relacionados mayoritariamente con el ámbito de psicología e ingeniería, y solamente pocos artículos están basados con temas de gestión y conceptos relevantes en relación a la seguridad operacional.

La revista más productiva, tanto en referencia al número total de artículos incluidos $(\mathrm{n}=16)$ y el total de citas ( $\mathrm{n}=463)$ ha sido el Journal of Air Transport Management. En segundo lugar, está la revista Safety Science, en cuanto al número total de artículos incluidos en el estudio $(\mathrm{n}=14)$, mientras que la segunda revista con mayor número de citas es el International Journal of Industrial Ergonomics, con 110 citas.

Los dos artículos más citados, ambos han sido publicados por Liou et al. en los años 2007 y 2008 con los títulos "Airline safety measurement using a bybrid model" y "Building an effective safety management system for Airlines", respectivamente.

A través de un análisis de redes ha sido posible la obtención de un mapa de co-ocurrencia entre las diferentes variables establecidas, resultado de la SLR y su posterior definición. Gracias a ello se ha podido adquirir una visión general sobre la estructura de la literatura básica de este tema de investigación. 
Los conceptos con mayor relevancia y peso relativo en referencia a la seguridad operacional han sido la gestión de la seguridad operacional (safety management) y los accidentes de avión (aircraft accidents), mientras que las aristas con mayor grado de interacción se han podido encontrar entre las mismas variables, como también entre la gestión de la seguridad operacional (safety management) y los incidentes de avión (aircraft incidents).

Además, se ha podido contemplar que la colaboración entre autores en los últimos años ha aumentado, un $69.5 \%$ de los referidos 59 artículos ha sido publicado por dos o más autores.

Hay un total de 13 investigadores con un mínimo de dos e incluso tres artículos publicados, donde destacan Chen, C.F. $(2012,2014,2014)$ y Chen, S.C. $(2012,2014,2014)$, habiendo colaborado tres veces entre ellos. Sin embargo, los 11 autores restantes, han colaborado con una gran diversidad de autores diferentes.

En relación a la co-citación, los autores citados con mayor frecuencia han sido Liou (2007, 2008) y Janic (2000) con 116 y 24 citas, respectivamente. La mayor co-ocurrencia se ha podido examinar entre los autores Liou y Huang $(\mathrm{n}=13)$ y Liou y Tsai $(\mathrm{n}=13)$.

Finalmente, se considera que el estudio realizado puede fomentar la visión sobre la aportación de la seguridad operacional a la gestión de las empresas del sector de transporte aéreo. Resaltar que la SLR realizada ofrece una oportunidad para futuras líneas de investigación con un enfoque más enfocado al management, ya que el estudio permite ver que la seguridad operacional, siendo un tema imprescindible en el ámbito del transporte aéreo, provee poca literatura académica relacionada con la gestión.

Otras posibles líneas de investigación futuras pueden ser, por lo tanto, las siguientes:

- Analizar, si es rentable la seguridad operacional para las compañías aéreas. Es decir, analizar cuál es el impacto que tiene la seguridad operacional sobre la rentabilidad de las aerolíneas.

- Estudiar, en que dimensión invierten las compañías aéreas en la seguridad operacional. Es decir, ver, cual es el porcentaje de gasto y/o inversión en la mejora de la seguridad operacional.

- Analizar cómo puede medirse la seguridad operacional en el transporte aéreo. Existen ya algunos indicadores sectoriales, como por ejemplo el JACDEC Safety Index desarrollado por JanArwed Richter y Christian Wolf (Richter, 2014), que ofrece información sobre accidentes e incidentes de aviones en los últimos años. 


\section{Referencias}

Acedo, F.J., Barroso, C., Casanueva, C., \& Galán, J.L. (2006). Co-Authorship in Management and Organizational Studies: An Empirical and Network Analysis. Journal of Management Studies, 43(5), 957-983. https://doi.org/10.1111/j.1467-6486.2006.00625.x

AERTEC (2013). Seguridad aeroportuaria: Safety \& Security. Por: José Antonio Poyato Moreira. Disponible online en: www.aerecsolutions.com. (Fecha del último acceso: Marzo, 2016).

Air Transport Action Group (ATAG) (2014). Disponible online en: www.atag.org. (Last access date: March, 2016).

Alves, H., Fernandes, C., \& Raposo, M. (2016). Value co-creation: Concept and contexts of application and study. Journal of Business Research, 69(5), 1626-1633. https://doi.org/10.1016/j.jbusres.2015.10.029

Aviation Safety Network (2016). Disponible online en: www.aviation-safety.net. (Fecha del último acceso: Marzo, 2016).

Banco Mundial (2015). Disponible online en: www.datos.bancomundial.org. (Fecha del último acceso: Marzo, 2016).

Barnett, A. (2009). Aviation Safety and Security. En: P. Belobaba, A. Odoni \& C. Barnhart (2009). The Global Airline Industry. Chichester (UK): John Wiley and Sons, Ed. https://doi.org/10.1002/9780470744734.ch11

Chang, Y.H., \& Yeh, C.H. (2004). A new airline safety index. Transportation Research Part B: Methodological, 38(4), 369-383. https://doi.org/10.1016/S0191-2615(03)00047-X

Chen, C.F., \& Chen, S.C. (2012). Scale development of safety management system evaluation for the airline industry. Accident Analysis \& Prevention, 47, 177-181. https://doi.org/10.1016/j.aap.2012.01.012

Chen, C.F., \& Chen, S.C. (2014). Investigating the effects of job demands and job resources on cabin crew safety behaviors. Tourism Management, 41, 45-52. https://doi.org/10.1016/j.tourman.2013.08.009

Chen, C.F., \& Chen, S.C. (2014). Measuring the effects of Safety Management System practices, morality leadership and self-efficacy on pilots' safety behaviors: Safety motivation as a mediator. Safety Science, 62, 376-385. https://doi.org/10.1016/j.ssci.2013.09.013

CRD. Centre for Reviews and Dissemination. (2009). Systematic Reviews: CRD's guidance for undertaking reviews in health care. Published by CRD, University of York.

Elsevier (2015). Disponible online en: www.elsevier.com. (Fecha del último acceso: Marzo, 2016).

European Aviation Safety Agency (2015). EAS A Annual Safety Review 2014. EASA. 
Fox, S. (2014). Safety and Security: The influence of 9/11 to the EU framework for air carriers and aircraft operators. Research in Transportation Economics, 45, 24-33. https://doi.org/10.1016/j.retrec.2014.07.004

Fruchterman, T., \& Reingold, E. (1991). Graph Drawing by Force-directed Placement. Software-practice and experience, 21, 1129-1164. https://doi.org/10.1002/spe.4380211102

Gill, G.K., \& Shergill, G.S. (2004). Perceptions of safety management and safety culture in the aviation industry in New Zealand. Journal of Air Transport Management, 10(4), 231-237. https://doi.org/10.1016/j.jairtraman.2004.02.002

Ginieis, M., Sánchez-Rebull, M.V., \& Campa-Planas, F. (2012a). The academic journal literature on air transport: Analysis using systematic literature review methodology. Journal of Air Transport Management, 19, 31-35. https://doi.org/10.1016/j.jairtraman.2011.12.005

Ginieis, M., Sánchez-Rebull, M.V., \& Campa-Planas, F. (2012b). Los costes en el sector del transporte aéreo. Una revisión de la literatura internacional. Revista Iberoamericana de Contabilidad de Gestión, X(20).

Gmür, M. (2003). Co-citation analysis and the search for invisible colleges: A methodological evaluation. Scientometrics, 57(1), 27-57. https://doi.org/10.1023/A:1023619503005

International Air Transport Association (IATA) (2014). Disponible online en: www.iata.org. (Fecha del último acceso: Febrero, 2016).

International Civil Aviation Organization. ICAO. (2015). Safety Report 2015 Edition.

Janic, M. (2000). An assessment of risk and safety in civil aviation. Journal of Air Transport Management, 6(1), 43-50. https://doi.org/10.1016/S0969-6997(99)00021-6

Kalemba, N., \& Campa-Planas, F. (2016). An overview of the Quality Concept in the Air Transportation Business: A systematic Literature Review. In press.

Kelemen, Z. (2003). Latest information technology development in the airline industry. Periodica Polytechnica Ser. Transp. Eng., 31(1-2), 45-52.

Kitchenham, B. (2004). Procedures for performing systematic reviews. Joint Technical Report. Keele University.

Latorella, K.A., \& Prabhu, P.V. (2000). A review of human error in aviation maintenance and inspection. International Journal of Industrial Ergonomics, 26(2), 133-161. https://doi.org/10.1016/S0169$8141(99) 00063-3$

Lee, W.K. (2006). Risk assessment modeling in aviation safety management. Journal of Air Transport Management, 12(5), 267-273. https://doi.org/10.1016/j.jairtraman.2006.07.007 
Liao, M.Y. (2015). Safety Culture in commercial aviation: Differences in perspective between Chinese and Western pilots. Safety Science, 79, 193-205. https://doi.org/10.1016/j.ssci.2015.05.011

Liou, J.J.H., Tzeng, G.-H., \& Chang, H.-C. (2007). Airline safety measurement using a hybrid model. Journal of Air Transport Management, 13(4), 213-220. https://doi.org/10.1016/j.jairtraman.2007.04.008

Liou, J.J.H., Yen, L., \& Tzeng, G.H. (2008). Building an effective safety management system for airlines. Journal of Air Transport Management, 14(1), 20-26. https://doi.org/10.1016/j.jairtraman.2007.10.002

McFadden, K.L., \& Hosmane, B.S. (2001). Operations safety: An assessment of a commercial aviation safety program. Journal of Operations Management, 19, 579-591. https://doi.org/10.1016/S02726963(01)00062-6

Netjasov, F., \& Janic, M. (2008). A review of research on risk and safety modelling in civil aviation. Journal of Air Transport Management, 14(4), 213-220. https://doi.org/10.1016/j.jairtraman.2008.04.008

NodeXL (2013). Disponible online en: www.nodexl.codeplex.com. (Fecha del último acceso: Marzo, 2016).

Pacheco, R.R., Fernandes, E., \& Domingos, E.M. (2014). Airport airside safety index. Journal of Air Transport Management, 34, 86-92. https://doi.org/10.1016/j.jairtraman.2013.08.007

Rankin, W., Hibit, R., Allen J., \& Sargent, R. (2000). Development and evaluation of the Maintenance Error Decision Aid (MEDA) process. International Journal of Industrial Ergonomics, 26(2), 261-276. https://doi.org/10.1016/S0169-8141(99)00070-0

Richter, J.A. (2014). The JACDEC Data Base. User Guide Explanations and Definitions. Hamburg: JACDECGbr.

SCImago Journal Rank (2014). Disponible online en: http://www.scimagoir.com/. (Fecha del último acceso: Marzo, 2016).

Scopus (2015). Disponible online en: http://www.scopus.com/. (Fecha del último acceso: Marzo, 2016).

Seguí-Mas, E., Sarrión-Viñes, F., Tormo-Carbó, G., \& Oltra, V. (2016). Producció científica en el camp de les spin-off acadèmiques: Una anàlisi bibliomètrica. Intangible Capital, 12(1), 246-267.

Shappell, S., Detwiler, C., Holcomb, K., Hackworth, C., Boquet, A., \& Wiegmann, D.A. (2007). Human error and Commercial Aviation Accidents: An Analysis Using the Human Factors Analysis and Classification System. Human Factors, 49(2), 227-242. https://doi.org/10.1518/001872007X312469

Taylor, J.C. (2000). The evolution and effectiveness of Maintenance Resource Management (MRM). International Journal of Industrial Ergonomics, 26(2), 201-215. https://doi.org/10.1016/S0169-8141(99)00066-9 
Webster, J., \& Watson, R. (2002). Analyzing the past to prepare for the future: Writing a literature review. MIS Quarterly, 26(2), 13-23.

Intangible Capital, 2017 (www.intangiblecapital.org)

Article's contents are provided on an Attribution-Non Commercial 3.0 Creative commons license. Readers are allowed to copy, distribute and communicate article's contents, provided the author's and Intangible Capital's names are included. It must not be used for commercial purposes. To see the complete license contents, please visit http://creativecommons.org/licenses/by-nc/3.0/. 